\title{
CARBONATE DEPOSITION, PHYSICAL LIMNOLOGY AND ENVIRONMENTALLY CONTROLLED CHERT FORMATION IN PALEOCENE-EOCENE LAKE FLAGSTAFF, CENTRAL UTAH
}

\author{
NEIL ANDREW WELLS \\ Museum of Paleontology and Department of Geological Sciences, The Universily of Michtgan, Ann Arhor, \\ $M I 48109$ (USA)
}

(Received July 27, 1982, revised and accepted March 9. 1983)

\section{ABSTRACT}

Wells, NA, 1983 Carbonate deposition, physical limnology and environmentally controlled chert formation in Paleocene-Eocene Lake Flagstaff, central Utah Sediment Geol, 35 263-296

Lake Flagstaff (Paleocene-Eocene of central Utah) owed its existence. large size, shallowness and low clastic content to its tectonic setting, but the climate controlled its mostly autochthonous sediments Durıng the first and most humid of the three lake phases, the lake was fresh, calcareous, large, and highly productive, with abundant vegetation and snails The first deposits were limestones with gradually increasing detrital dolomite eroded from lake-marginal carbonate mudflats that were undergoing penecontemporaneous dolomitization Continuous fluctuation in lake level produced many secondary dewatering and pedogenic-paludine fabrics The lake developed into a playa lake during the very arid second phase, becoming restricted in area and fauna The water was salıne and alkalıne, and twice became a gypsum-precipitating brine Frequent exposure of the lake beds resulted in much calichification and in rapid and complete dolomitization Under the intermediate climate of the third phase, the lake reexpanded and freshened, snaıls returned, and many lımestones escaped dolomitization Each phase defines a member of the Flagstaff Formation

Chert, absent in the oldest beds, increases up-section The lowest chert forms minor small spheres and linings in voids near the top of the lowest member, suggesting limited silica input and post-dolomitization precipitation in areas of greatest groundwater movement The base of the middle member contains horizons of atextural chert mudcrack fillıngs and nodules that appear to have been an inorganically precipitated gel Most of the middle member, however, contains abundant chert nodules that replaced limestone prior to dolomitization The nodules grew prior to burial (some even prior to mudcrack formation) by the movement of dissolved silica to areas of relatively low $\mathrm{pH}$ In the upper member, chert is even more prevalent entire thin beds were pervasively but incompletely silicified prior to dolomitizdtıon, probably by vertical evaporative pumping of silıceous groundwater moving under mudflats toward the lake

\section{INTRODUCTION}

In the last decade, studies of carbonate lake deposits have been very successful in interpretıng paleolimnology (e g. Reeves, 1968, 1972, Freytet, 1973; Muller and 

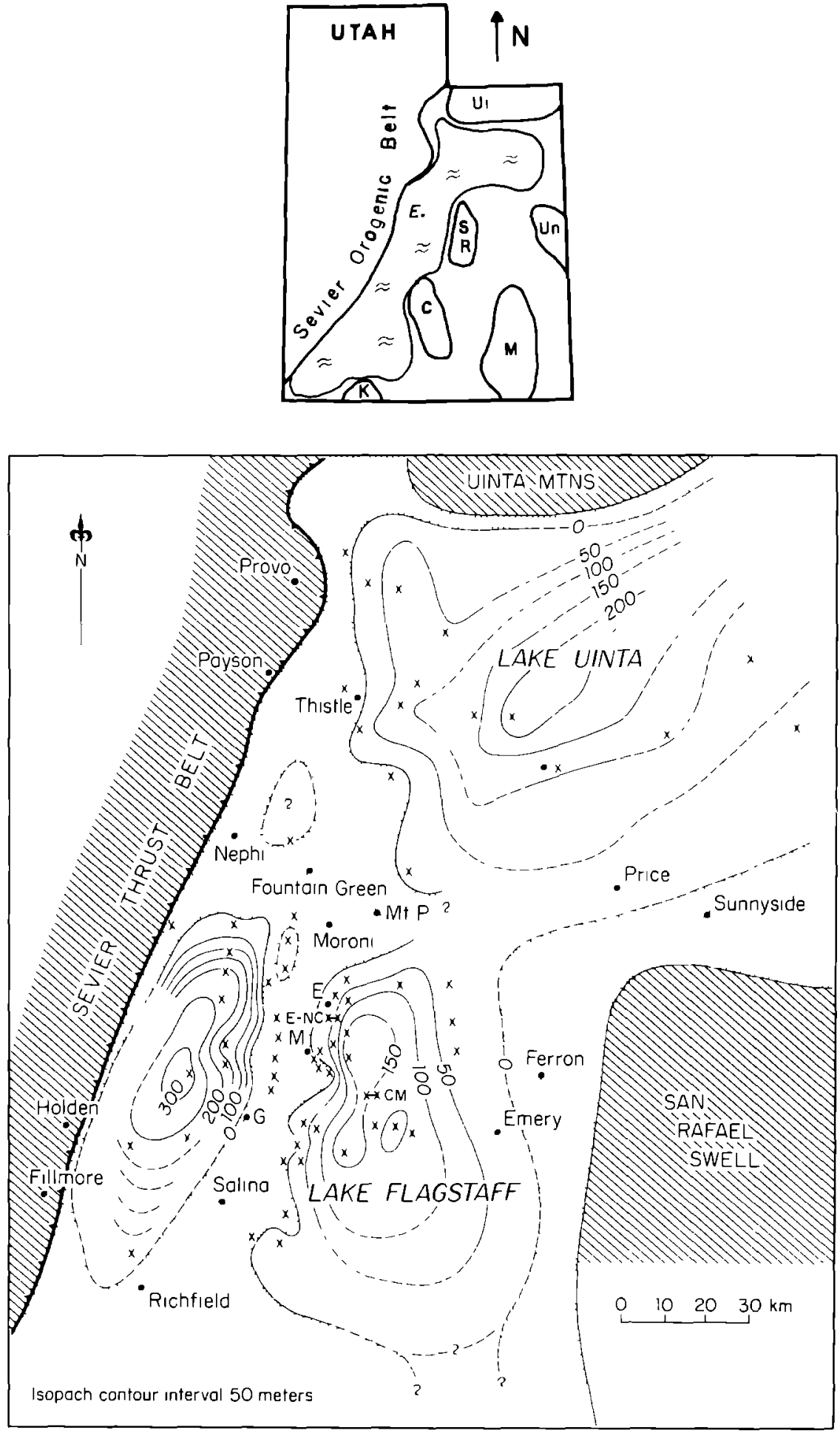
Wagner, 1978) Some of the great early Tertiary lakes of western North America have been important in this research, in part due to their unusual authigenic minerals, and their development is now quite well known (e.g. Williamson and Picard. 1974, Eugster and Hardie, 1975. Surdam and Wolfbauer. 1975; Ryder et al.. 1976) Paleocene-Eocene Lake Flagstaff of central Utah (Fig 1) has none of the unusual minerals of the better known Green River lake system to the north, but it does show significant changes during development for it changed from a large, shallow, calcareous, hardwater lake to a gypsum-precipitatıng playa lake and back again This paper will investigate the physical limnology of the lake through petrographic study of 1ts deposits, with emphasis on the predominant limestones and dolostones and on the much less abundant chert.

Chert deposition in the Flagstaff Formation is significant because its manner of occurrence seems to have been environmentally controlled, changing in response to climatically induced changes in the physical character and water chemistry of the lake. The extent of variation in occurrence that is seen in the Flagstaff is, for any one deposit, unusual, and thus understanding the variability and sensitivity of the silica cycle in this lake becomes important. In order to interpret the chert, the paleoenvironment and paleolımnology of the lake will first be discussed. The following is summarized from Wells (1977) and McCullough (1977)

\section{THE FLAGSTAFF FORMATION}

\section{Geologic settıng}

Lake Flagstaff was the central part of a major lake system that extended SW-NE across Utah (La Rocque, 1960). Its deposits are part of a sequence of late Cretaceous through Eocene strata that has been divided (from oldest to youngest) in to the Price

Fig 1. Isopach map of the Lower or Ferron Mountain Member of the Flagstaff Formation, showing the different depocenters The lakes were surely much smaller than the basıns and shifted around withın them, so the isopachs indicate frequency of lacustrine conditions rather than bathymetry The small map of Utah shows the possible extent of the Flagstaff Formation (marked by waves) Both maps show the town of Ephraim (marked $E$ ) and nearby tectonic uplifts (diagonally ruled on the larger map) The Sevier Thrust Belt is a Mesozoic feature, from which plains had dipped gently eastward The lakes were formed by ponding of water during reversal of the paleoslope by Laramide uplifts ( $U I$ = Uinta Mountains. $S R=$ San Rafael Swell, $U N=$ Uncompahgre, $M=$ Monument, $C=$ Circle Clıffs, and $K=$ Kalbab) On the larger map, the stıppled areas show the clastic North Horn and Colton ("Wasatch") floodplains around the lakes Some town names are abbreviated from the north, $M t P=$ Mount Pleasant, $E=$ Ephram, $M=$ Mantı, and $G=$ Gunnıson The two pairs of joined X's mark the Cove Mountain/Skylıne Drive $(C M)$ and Ephrain Canyon/New Canyon ( $E-N C$ ) sections described in Fig 2 The other X's locate sections, both ours and those of the many previous geologists, mostly Ohıo State students, who have worked in the area (they are listed fully in theses by Wells and McCullough) Partial sections are not marked 
Rıver, North Horn, Flagstaff, Colton and Green Rıver Formations. The Price Ruver and North Horn Formations are composed of debris shed eastward from the previously folded Sevier orogenic belt (Spieker, 1949; Harris, 1959; Armstrong, 1968) across flat coastal plains to the sea then over Colorado (Hunt, 1956). Laramide uplifts in the eastern half of Utah reversed this drainage and caused ponding, which created Lake Flagstaff The Flagstaff Formation is therefore essentially the bodies of lake deposits left by Lake Flagstaff and associated minor lakes and is enclosed by the supralacustrine North Horn and Colton floodplain sediments (for details and history of research see Wells, 1977, pp 19-30)

The Wasatch Plateau lithosome of the Flagstaff Formation, the subject of this research, is almost pure carbonate, consistıng of alternatıng thin beds of well-lithified micritic limestone or dolostone and friable calcite or dolomite "mudrocks" that break down into angular blocky granules It is readily divided on the basis of fossils

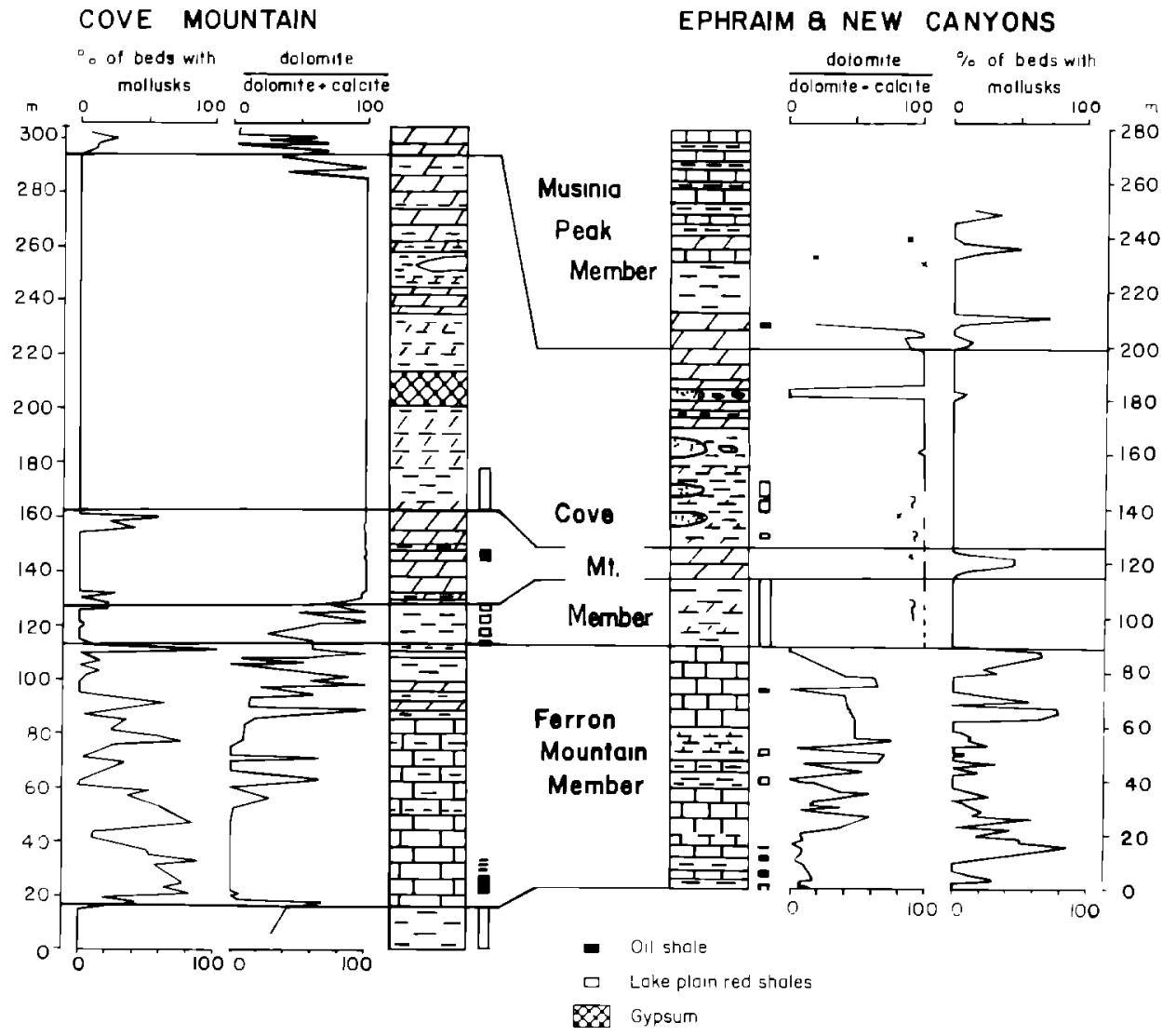

Fig 2 The Cove Mountain and Ephraim Canyon/New Canyon sections showing the dolomite proportion of the carbonate ( 175 and 60 analyses, respectively), the abundance of mollusks (data summed every $2 \mathrm{~m}$ ), and the rock types 
or lithology into three units (McCullough, 1977), which from bottom to top have been named the Ferron Mountain Member, the Cove Mountain Member, and the Musinia Peak Member (Stanley and Collınson, 1979) The units are each on the order of $100 \mathrm{~m}$ thick (Fig. 2). Basic petrographic data for each member are given in Table 1

Of the three members, the Ferron Mountain Member is the most fossiliferous and the most calcareous It is also largely chert-free, although near the top of the member some rocks are quite dolomitic and contain some small spheres and linings of chert in voids. In contrast, the Cove Mountain Member is characterized by completely dolomitized white beds with large chert nodules and no snails, and contains horizons of gypsum and red mudstone. The Musınıa Peak Member again contains snals and less-than-completely dolomitized carbonates, although there are still many pure dolostones. Chert is abundant as thin but extensive silicified limestone beds The changes to and from the middle member rock types are gradual, but the limits have been placed according to the disappearance and reappearance of snats Conditions of complete dolomitization were attained somewhat after their disappearance and were lost just a little before their reappearance (see Fig 2).

\section{The Ferron Mountain Member}

The Ferron Mountain Member consists primarily of thinly bedded grey limestones and mudrocks The limestones are mostly micritic, with varying amounts of lacustrıne snaıls, ostracodes, peloıds and micritıc and dolomicritic intraclasts, and they contain an average of $10 \%$ insoluble material (60 samples, standard deviation $=$ 6 points) The mudrocks are fine-grained, homogeneous, slope-forming units composed of calcite with or without dolomite that are usually described as clay-rich but which average only $16 \%$ clay $(n=11, s . d .=17)$. Dolomite is absent trom the lowest $50 \mathrm{~m}$ of the member but becomes more abundant upward. Near the top of the member there are a few pure, vuggy, white dolostone beds that are clearly shown to be dolomitized limestones by their remnant fossils and fabrics Chert is similarly absent from the base of the member, but toward the top it is present in voids as fillıngs and small spheres

Many features of the micrites indicate that shallow-water and marsh or weed-bank environments were common in the Flagstaff, particularly in the eastern deposits The micrites are quite similar to mostly Paleogene paludine and lacustrine limestones described from southern France by Freytet (1973) The commonest attributes of the micrites are their rootlets, snaıls, dewatering cracks, solution-remobilization features, and intraclasts

Rootlets. The abundance of vegetation is shown by the varied and abundant root and rootlet moulds (Figs. 3A. B and 4C). Roots are best distinguished from burrows when they narrow and do not rejoin after branching The walls of many root tubes show mobilization of calcite due to release of $\mathrm{CO}_{2}$ Roots may be subaqueous, but 


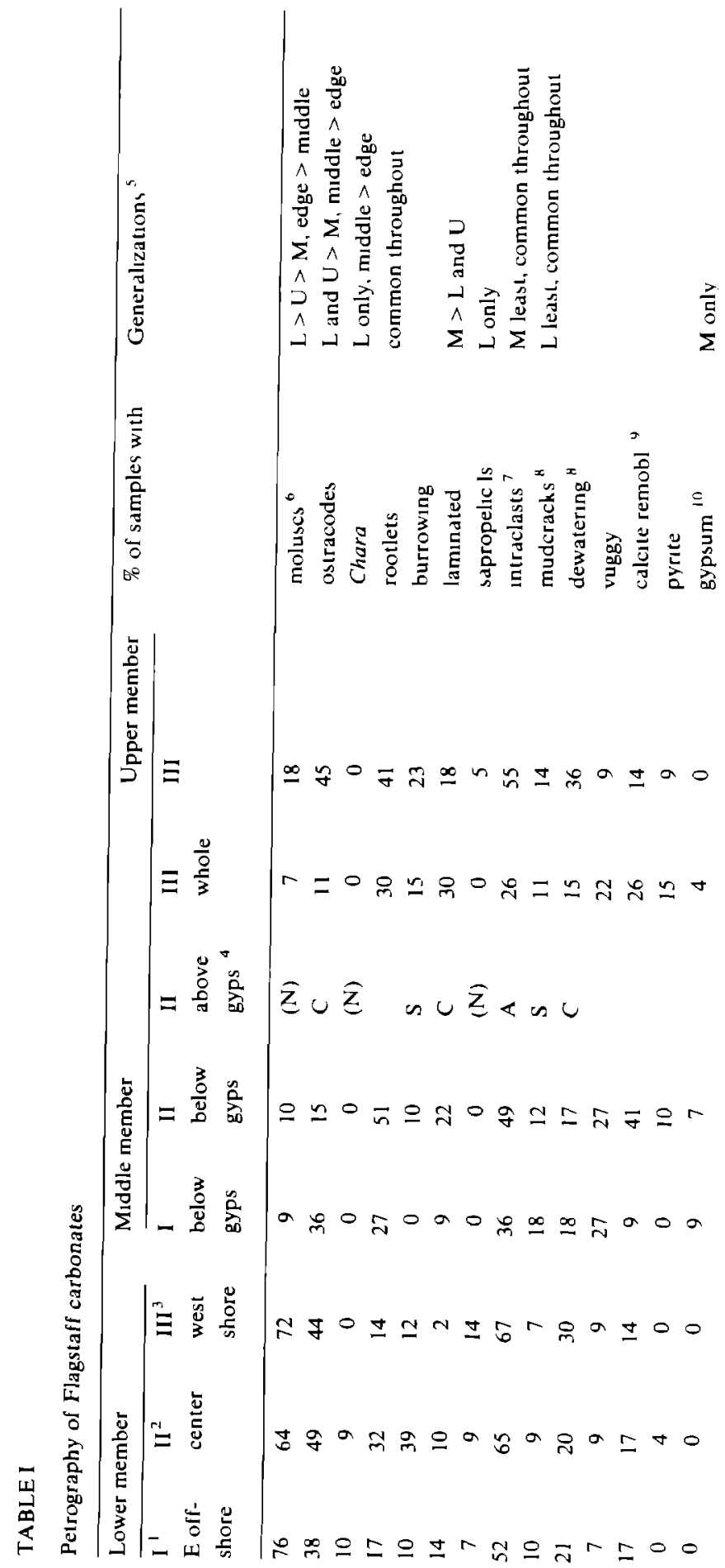




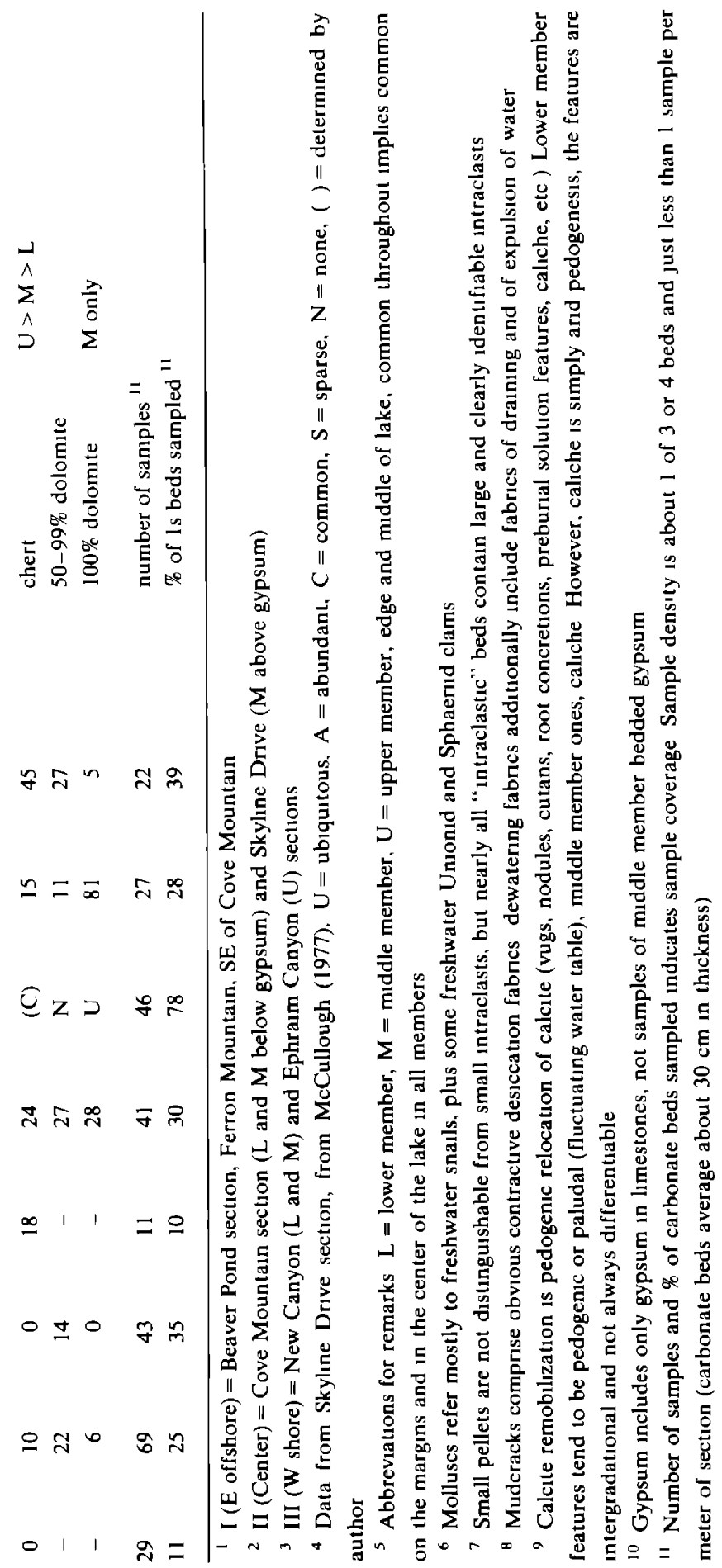




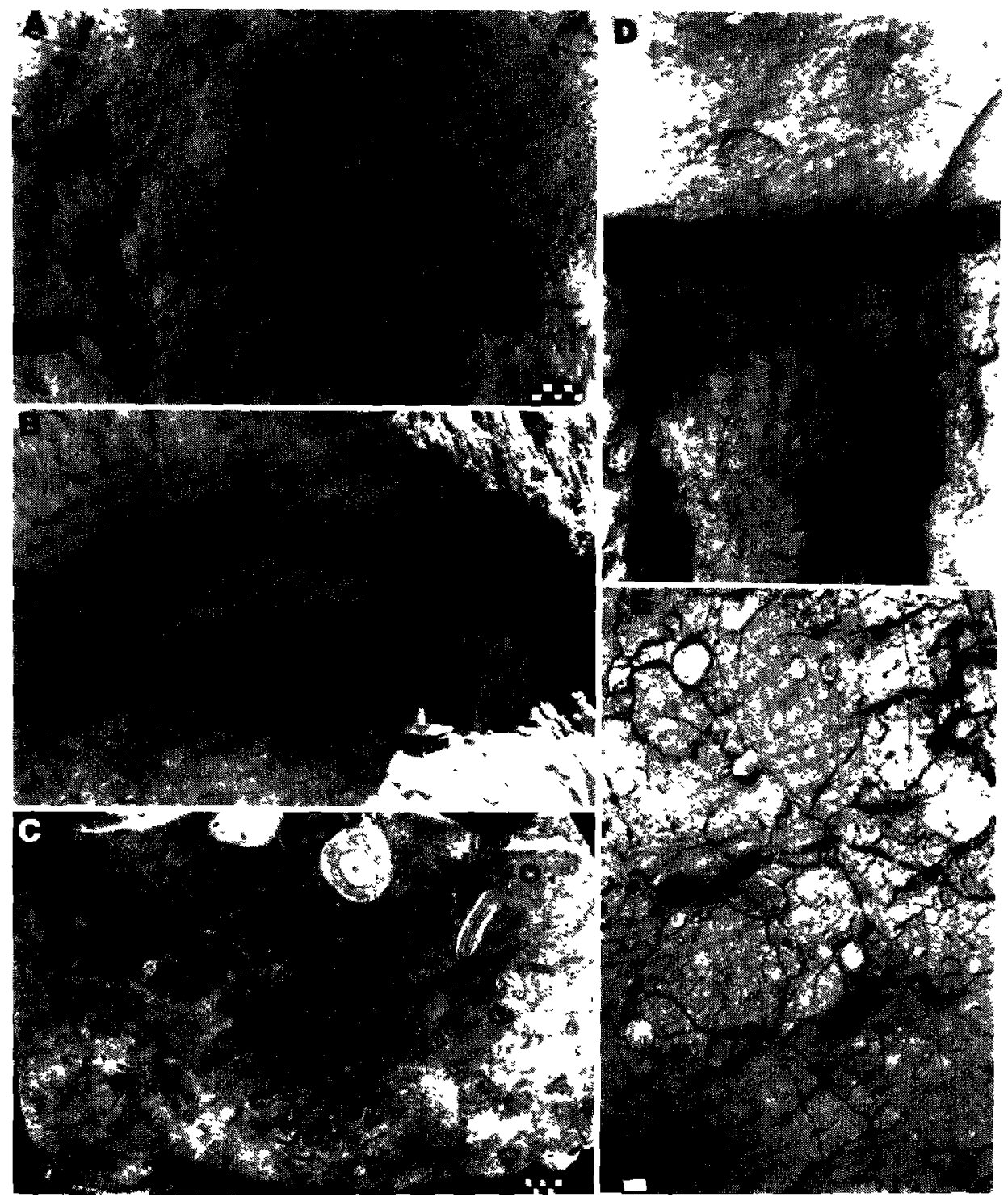

Fig 3 A Dendroıd roollet moulds, in middle unıt of Cove Mountaın Member, Cove Mountaın Rootlet networks are rarely this obvious, and many do not branch Scale is $5 \mathrm{~mm}$ B Pedotubules formed by mobılization of carbonate around rhızomes or roots. Paludal facıes, Long Rudge $C$ Marmorized oncolitic limestone from Birdseye Quarry near Indianola, on western shore of lake Darker areas are red (5R 5/5) from hematite and the lighter are yellow (10Y to $5 Y R$ 6/4) from limonite Most oncolites formed around Gontobasis snails or twigs D Nodular or knobby columnar limestone, caused by solution of calcite due to aspiration of $\mathrm{CO}_{2}$ by vertical roots and to oscillations of the water table (Freytet. 1973) The overlying bed is one of the rare fluvial sandstones Ferron Mountain Member, Flagstaff Peak E Strong development of microscopic curved and planar "craze planes" (Brewer, 1964, p 198) with larger nonplanar shrinkage pores and nodule development The larger nodules locally control patterns of contraction Negative print of thin section (looks like polıshed slab); Wales Canyon l-mm scale Probably Ferron Mountan Member 
well-rooted and surface-attaining vegetation is limited to water shallower than about $3 \mathrm{~m}$ (Dussart, 1976). The larger roots (Fig. 3B) and radicular aspiration fabrics, particularly vertical ones like "columnar limestones" (Fig 3D), probably formed at or above the water table. That the lake was weedy rather than swampy is shown by the rarity of extensive organic deposits and pyrite.

Snals La Rocque's study of the Flagstaff snails led him to conclude that the early lake was shallow, wave-swept, well-aerated, and turbid, with a soft muddy bottom and abundant vegetation (La Rocque, 1960). Applying Hanley's (1977) descriptions of snall associations to La Rocque's published collections (La Rocque, 1960; see also Gill, 1950) shows that the Flagstaff snails belong to the "pond" and, to a lesser extent, "littoral lacustrıne" associations. Accordıng to Hanley, "pond" snails could withstand episodic desiccation and indicate quiet water, such as ponds or, presumably, shallow lake waters protected by vegetation, whereas "littoral" snails represent shallow, nearshore, current-swept, poorly vegetated sites and "delineate shoreline fluctuations".

Remobllization features. Flagstaff rocks contain many examples of preburial solution and localized redistribution of iron, calcite, silica and clays. These can be thought of as early soil fabrics related to oscillation of the water table Marmorization, or splotches of colours typical of iron oxides and hydroxides (F1g 3C), is locally common and indicates alternatıng oxic and reducing conditions (Golterman, 1967), as could occur by alternate drainage and flooding (Freytet, 1973). Calcite solution and reprecipitation are more common. Nodules abound, and many are surrounded by a friable, white, porous, leached zone. Characteristic repeated fissuring and growth may form during oscillation of the water table (Freytet, 1973) and by associated stresses of cementation or recrystallization (Thury, 1981) Most of the beds with nodules, plus some others, have knobby or hummocky tops which are either decalcified or, more rarely, have a thin crust. Alteration occurred before burial, because the overlying beds are never affected Such tops might be hardground-like features formed during periods of undersaturation of the lake water, but on the strength of the commonly associated remobilization and pedogenic features they are believed to have been formed after exposure owing to rain or to oscillation of the water table at the surface (compare Walkden, 1974). Also common are fabrics that indicate onset of solution prior to lithification. The most important examples are the oozing of micrite into voids caused by the dissolution of shells and formation of protostylolites where the walls of rootlet moulds have squashed together. These are not necessarily paludine features, but are often associated with them.

Dewatering cracks Many micrites are "cracked" or brecciated These fabrics, listed as dewatering fabrics in Table I, include. (1) rare megascopic V-shaped mudcracks, (2) widespread microbreccia-lıke mosaics of spar-filled hairlıne cracks (Identifiable as joint, skew and craze planes of Brewer, 1964; Fig. 3E), and (3) common macroscopic brecciation by irregular, small, vertical and horizontal cracks and closed vugs (Identıfiable as the prism cracks, sheet cracks and shrinkage pores of 

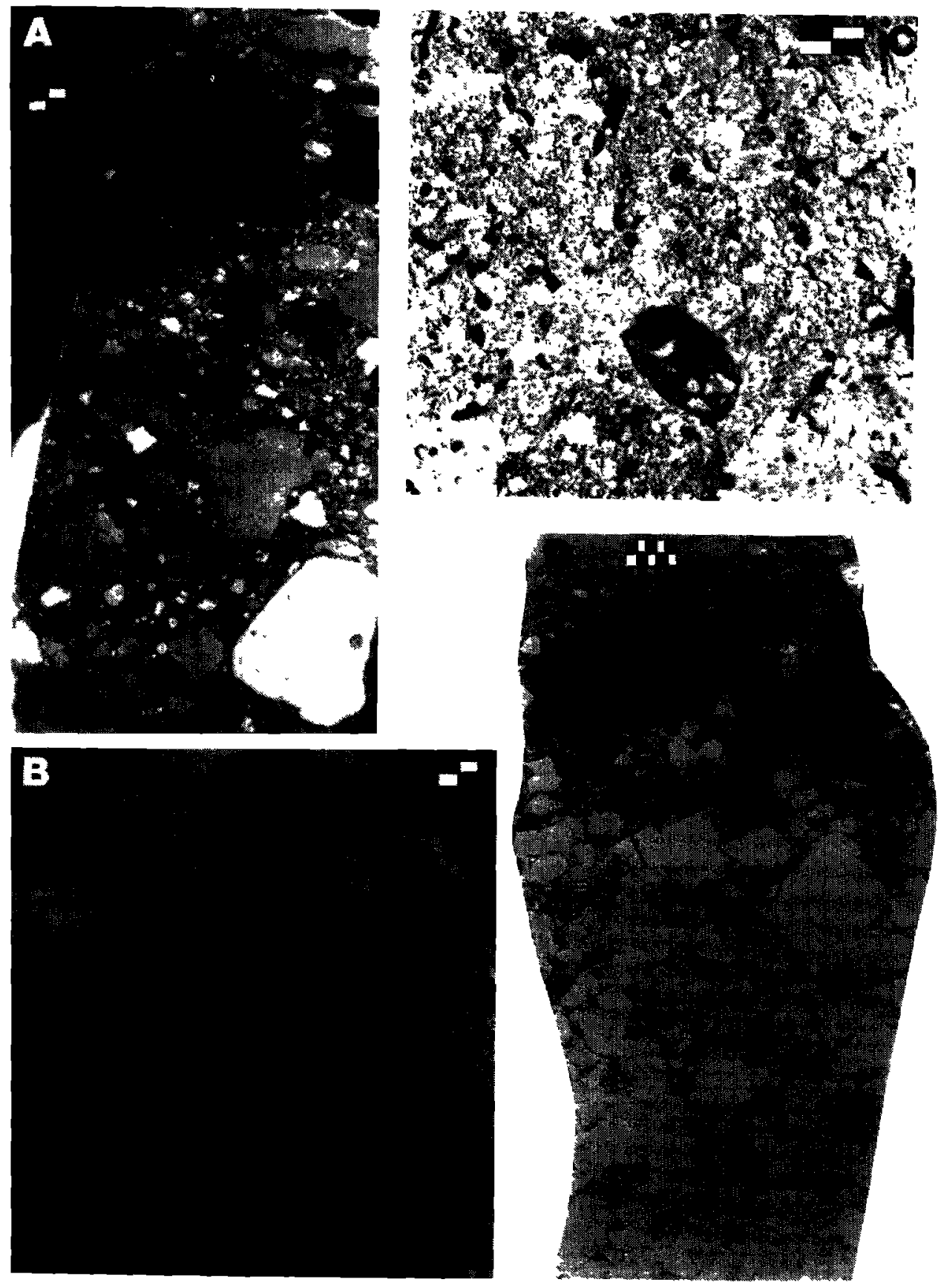

Fig 4 A Relatıvely coarse polylıthologic intramicrudite All clasts are calcareous but differ in size, colour, roundness, fossil content, etc Ferron Mountain Member, Cove Mountain 5-mm scale B These clasts are either calcitic (stained dark) and derived from the top of the bed below or they dre dolomitic (unstained) The influx of dolomitic debris apparently loosened and removed sections of calc-micrite 
Fischer, 1964). Many sheet and prism cracks are recognizable as polygonal mudcracks that have been partly obliterated by secondary collapse of the mudcrack walls (F1g. 5D, E) They and the shrinkage pores are filled with biogenic and intraclastic detritus, calcilutite, and spar. The lack of disturbance of the bases of overlying beds suggests that the cracks were produced by dewatering and contraction of soft, wet sediment prior to burial The unusual, macroscopic, horizontal pulling apart of a thin layer of micrite in an otherwise undisturbed bed also suggests dewatering of the sediment

Intraclasts. The Flagstaff micrites are dominated by clasts of micrite or dolomicrite (Fig 4). The lithologies and colors, plus distinctive fossils, textures and fabrics in the larger clasts, identify them as intraclasts despite their great variation in size, shape, angularity and degree of deformation Indeed, clasts can frequently be identified as coming from the underlyıng bed (Fig. 4B). The size, angularity and deformation of the clasts depends on the degree of lithification before erosion and the amount of reworkıng prior to deposition. Freytet (1973) explains that originally unlithified material disintegrates to mud on erosion and transportation whereas well-lithified material results in angular clasts. Intramicrites of rounded and slightly deformed intraclasts are perhaps the most common sediment in the Flagstaff, indicating that erosion of large amounts of moderately soft and partly lithified carbonate mud was very common.

Three particular types of intramicrites are noteworthy First, there are a few beds with clasts of only one lithology, demonstrably derived from the underlying bed, that suggest by the persistently great range in clast size (always from fine sand to granules or even medium pebbles) that the clasts were formed in different sizes (Fig. 4C, D) Second, examination of the mixed dolomite-calcite beds shows that the dolomitic fraction is detrital dolomicrite, in similarly variably sized clasts. The largest dolomicrite clasts contain evidence, such as "ghosts" of freshwater snails, ostracodes and rootlet moulds, that they are clasts of Flagstaff dolomitized micrite The presence of dolomite clasts in micrite but never the reverse shows that (1) the dolomitized clasts were already dolomitized when deposited; and (2) the sites of dolomitization were topographically higher than the sites of deposition of micrite Together, the evidence suggests that dolomitization occurred locally or occasionally on carbonate mudflats surrounding the lake Third, most of the small, 1-3 mm,

\footnotetext{
previously disjoined by skew planes, which resulted from internal contraction Undisturbed skew planes are also present in the micrite at top center Ferron Mountain Member, Cove Mountain 5-mm scale C Silıcified limestone composed of relatıvely angular silı to granule sized intraclasts of an ostracodal micrite Voids include mollusk and ostracode moulds. rootlet moulds, many small interparticle voids, and indeterminate channels All voids in the micrite clasts are ostracode moulds or associated shrinkage cracks Musınıa Peak Member, Ephraım Canyon 2-mm scale D Mostly intraclasts of a white dolomicrite in a limestone matrix The moderately high angulanty of the clasts implies little abrasion and suggest, that the wide range in size is primary Ferron Mountain Member, Ferron Mountain 5-mm scale
} 

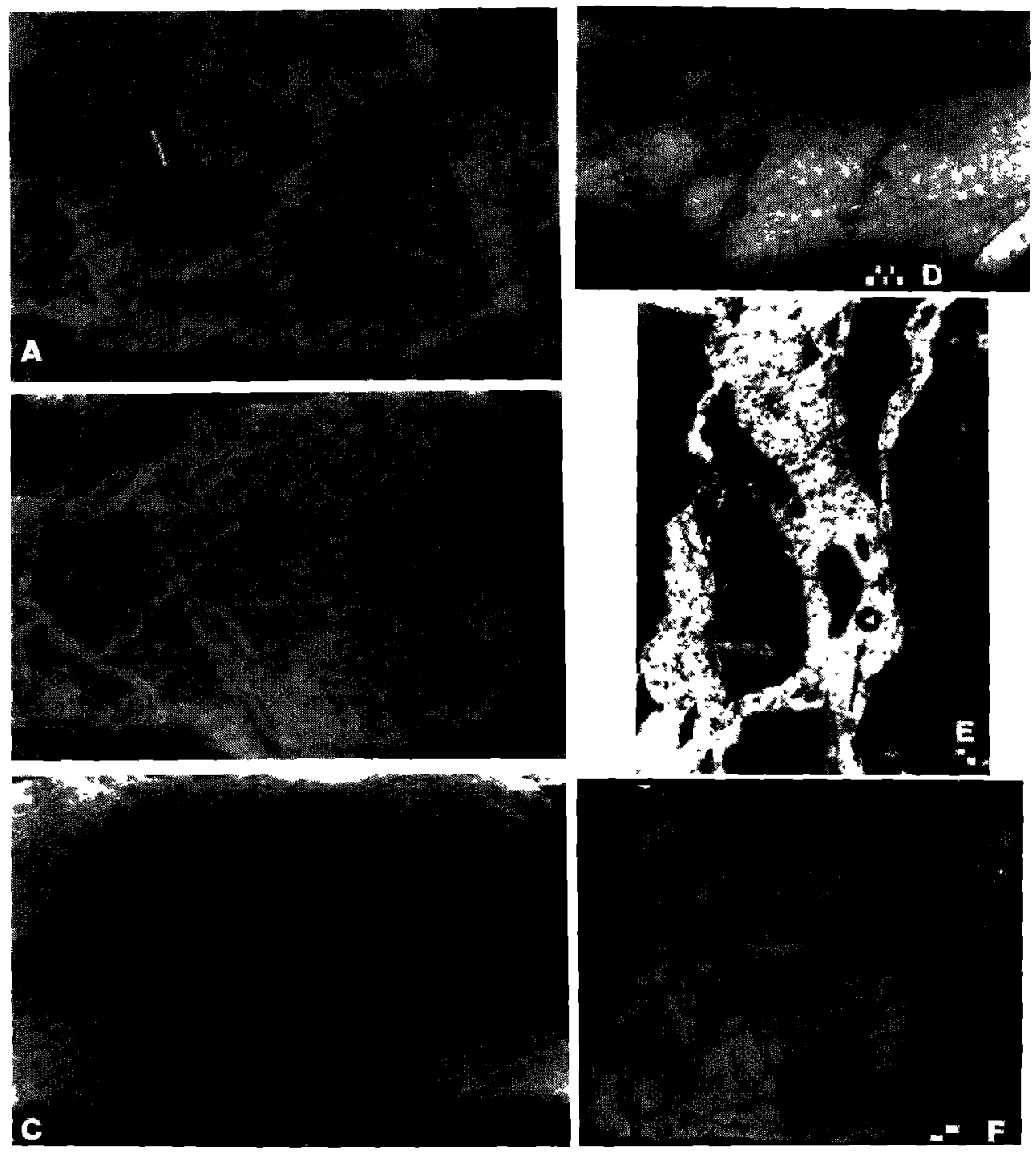

Fig 5 A Top view of a polygonal network of V-shaped mudcracks filled with dolomite in chert that has replaced limestone Cove Mountain Member, Cove Mountain B and C. Respectively, the top and side views of straight-sided mudcracks (in a herarchy of sizes) in and filled with dolomite Cove Mountain Member, Cove Mountain D Sheet and prism cracks (Fischer, 1964) debris-filled horizontal and vertical components of mudcracks that have undergone minor compaction but also extensive sidewall collapse and secondary cracking Ferron Mountain Member 5-mm scale E Sidewall caving-failure of the walls of a spar-filled prism crack. Transmitted light Scale is $01 \mathrm{~mm}$ F Calıche features-calıche breccia with stylolites and recrystallized sparry area (in center) Cove Mountain Member, southern Wasatch Plateau Scale is $50 \mathrm{~mm}$ 
round, somewhat deformed "pelords" that compose many limestones seem to have been small intraclasts winnowed from moderately soft dolomite or calcite muds, rather than fecal pellets (see Smoot, 1978) Freytet (1973, fig 3) discusses the usual diagenetic alteration of these peloidal limestones by compaction, solution-compactıon, neomorphism, etc, from "gravelly" or clearly intraclastic limestone to "grumelous" or greatly homogeneized limestone with perhaps only stellate interpelletal spar to show the pellets' former existence (Fig 7G).

The clasts in the intramicrites most likely formed by the mechanical reworking of internally contracted micrites, for dewatering imparts moderate cohesion to the muds while associated complex secondary cracking and collapse of the walls of mudcracks produces numerous small clasts of variable size and shape. Fine mosaics of joint, craze, or skew planes could easily produce the smallest, peloidal, clasts (Figs 3E, 4B and 5C) Internally contracted micrites are sufficiently common throughout the lake basin to account for all the intraclasts and they would certainly be most abundant in higher and more frequently exposed areas, which seem most subject to reworkıng. Reworkıng could occur by waves or bottom currents (Vatan, 1939), or sheetwash floods, or shifting of the wave base by frequent regressions and transgressions over mudflats (Eugster and Hardie, 1975). Frequent exposure and re-inundation need not be caused by changes in the volume of the lake, for winds can readily move water off or onto marginal mudflats or even, in flat playa basins. move an entire lake (Motts, 1970). Reworking would probably have been favored whenever the lake expanded because wave action would be increased due to a greater fetch and the flooding of wave-baffling littoral vegetation.

Evidence for shallow-water weed beds and pedogenesis at or near the water table is present throughout the lowest member of the Flagstaff Formation, but such features are most abundant in a very wide belt along the eastern side of the lithosome (suggesting that the eastern shore was very flat, shallow and weedy) and less so along the western side (where paludine features are associated with hematitic. sandy, oolitic and oncolitic limestones, indicating a narrower, more clastic, and higher-energy shore; see Weiss, 1969). These associations are best seen at the western edge of the Wasatch Plateau (e g, Fig 3C) and along its eastern top in partial sections not located on Fig. 1. In between, and even locally on the margins of the lake, are rock types that probably indicate deeper water, such as sapropelic limestones, low grade thinly laminated oil shales, ostracodal biomicrites, and micrites with Chara and (or) only gill-breathing snails. Nevertheless, even these deeper-water beds have superımposed paludine features or are interbedded with other beds with paludine features commonly enough to suggest that the lake was overall very shallow and that the floor was frequently exposed.

The frequency and extent of shallow-water indicators and of "pond" associations of snals might suggest that Lake Flagstaff was in fact a region of ponds and small lakes This may be true regionally, but the very extensive, flat, sharp and parallel bedding surfaces show no evidence of pinching out where traceable tor 


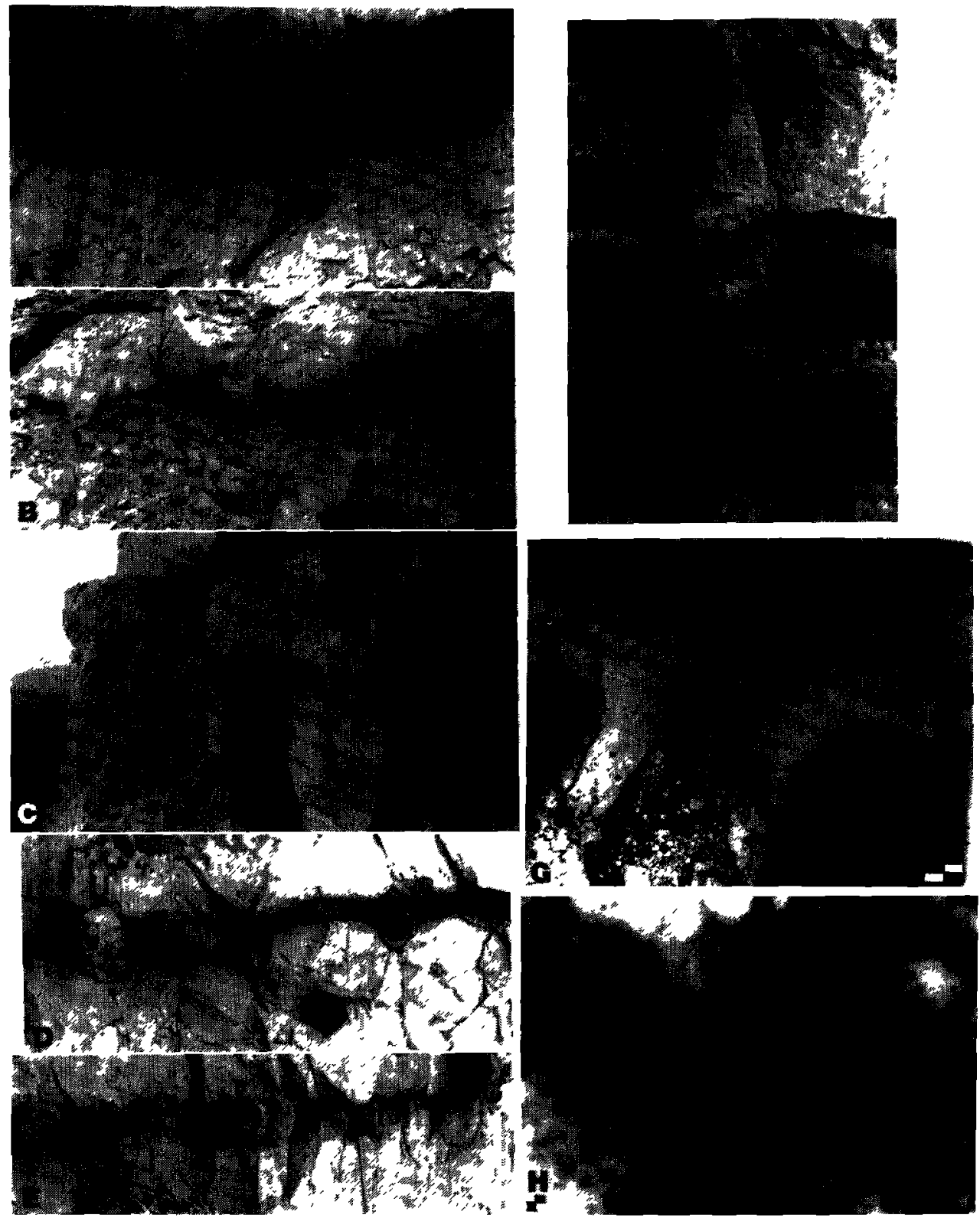

Fig. 6 A. Mudcracks, in laminated calcilutite and filled with a limestone that is distinct from the overlying limestone prior to the dewatering and compaction of the calcilutite $B$ Rare Ferron Mountain Member V-shaped mudcracks in a laminated calcilutite and filled with the overlyıng limestone. otherwise imilar to A The extensive vertical fractures in the overlying bed may be water escape structures $\mathrm{C}$ Lower Cove Mountain Member horizon of chert nodules The nodules are evenly spaced, vertically oriented, and do not replace limestone They cannot be post-burial because they do not lie on a bedding plane or a joint Possibly they are mudcrack fillıngs like 6F Ferron Mountain D and E Two horizons of typical roughly spherical lower Cove Mountain Member chert nodules formed in a calcilutite bed prior to 
several kulometers over the Wasatch Plateau The omnipresent intramicrites and cracks filled with fine intraclasts and fossil debris argue that erosion and deposition during frequent regressions and transgressions, alded by preferential mudcrackıng in higher areas, were important in maintaining a very flat basin floor

Abundant brecciation, the early lithification, the abundant empty rootlet moulds. the thin but extensive beds, the frequent lack of stratıfication within beds, the fluctuatıng water table, the variable dolomite content, and the common early soil fabrics all make the lower Flagstaff very similar to the sediments of the ephemeral, vast, and extremely shallow Hungarian semyek lakes (Molnar et al., 1976) (A semyek comprises very flat and frequently shallowly flooded interfleuve plains ) The author pictures a similar but less ephemeral environment of deposition, rather, a more permanent and slightly deeper marl lake surrounded by extensive carbonate mudflats in a less open basin

\section{The Cove Mountain Member}

The middle or Cove Mountain Member essentially is completely dolomitic and contains no snails (see Fig. 2). However, the base of the member is transitional in dolomite content and there are two thin horizons of vuggy dolostones in the middle of the member that contain 1-10\% calcite and rare snail fossils Middle-Member dolostones are pure, fine grained and homogeneous. They are thought to be secondary', destructively replacing limestones after a period of silicification, because primary features such as lamınae, rootlet moulds, ostracodes, burrows, organic debris and grumelous fabrics are well preserved in chert nodules, but they are very faint or absent in the dolostones Nevertheless, secondary syn- or post-dolomitization features abound. Reworkıng has produced many intradolomicrites. Early solution features such as solution seams (Garrison and Kennedy, 1977) and incipient nodular bedding (Pettıjohn and Potter, 1964) are present. More important are the common, detritus-filled. simple to complex mudcracks (frequently distorted during

\footnotetext{
' One reviewer notes correctly that local primary fine-grained dolomites can not be ruled out where cherts are absent, but they cannot be demonstrated either, so I leave this controversy to others, e g Chilıngar et al, 1979, p $429 \mathrm{ff}$
}

\footnotetext{
its compaction Pen for scale at lower left in E Cove Mountain F Mudcrack in calcilutite filled with chert that hardened before compaction Compare to Fig 5B Note how the overlyıng dolomite was impaled on the nodule as the calcilutite was compressed Other chert mudcrack fillings on this horizon have been pushed down into the underlying dolomite as well Cove Mountain $G$ Negative print of typıcal Musınıa Peak Member sılıcıfıed mudcracked ostracodal micrite Note secondary crackıng and fıne intraclastic and bıogenic mudcrack filling Ephraım Canyon 2-mm scale H Upper Cove Mountam Member chert with dolomite intraclasts that are only partly replaced by spherules of silica pH-attuned fine-scale solution-replacement seems not to have been operative Reflected light 0 l-mm scale
} 


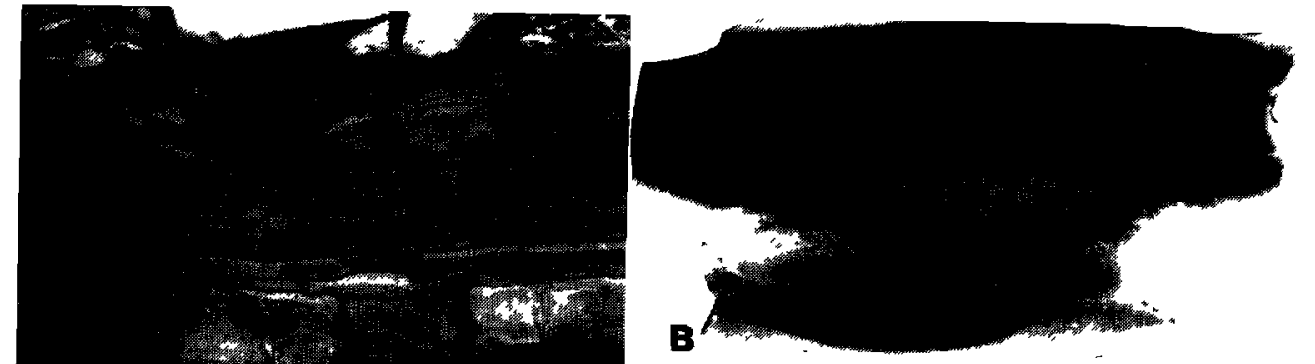

A
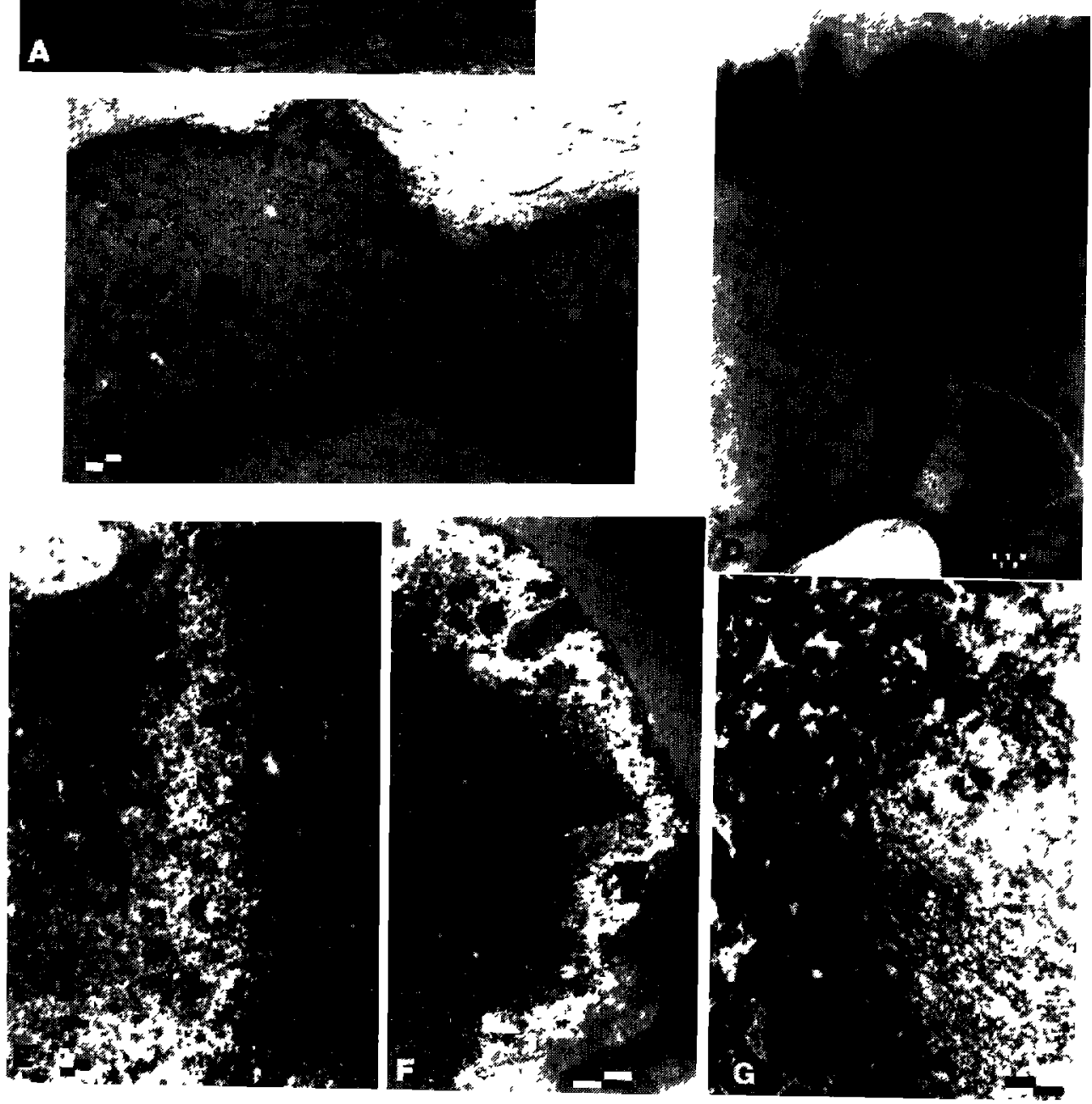

Fig 7 A Typical habits of Cove Mountain Member chert nodules All replace limestone and preserve laminae, etc, that are lost in the dolomite They also withstood compaction Note the unusually thin and extensive nodule dt top and the mudcrack below and to the right of the lens cap The dark edge of the largest nodule is due in a concentration of pyrite and silica spherules B Close-up of one nodule showing preservation of laminae The grey areas around the nodule are partly silicidified areas that were probably silicified after dolomitization The white flecks are "islands" of unilıcified dolomite The nodule is $7 \mathrm{em}$ 
burial into wavy vertical lenses-McCullough, 1977. Smoot, 1978) and the equally common preburial microcracks (generally craze and skew planes of Brewer, 1964), for they demonstrate considerable desiccation (Figs. 5, 6A and B). Similarly 1mportant are widespread caliche features such as caliche conglomerates or breccias (formed by recrystallization, Fig 5F), calıche crusts, pseudobedding, plates and blebs (diffuse, irregular segregations of a constituent of the matrix, a plasmic separation in the terminology of Brewer, 1964) (terms from Reeves, 1976, see Thiry, 1981, for more examples)

The middle member also includes two gypseous horizons (first recognized by Gill, 1950). The lesser consists of dolostones with sparse authigenic, detrital, and secondary gypsum crystals and crystal moulds, and the greater is a thicker and more extensive zone of thinly laminated gypsum. The gypsum units are restricted to the center of the lake basin and are surrounded by laterally equivalent red-weathered and decalcified shales, so they are interpreted as representing low stands of the lake Lake deposits in other Flagstaff basıns (such as the Juab Valley basin) seem to record a synchronous drying up (see the Appendix) The contraction of the lakes" shorelines, the precipitation of gypsum, and the abundant caliche and mudcracks indicate that the middle member underwent intense desiccation and evaporation Overall, the lake at this stage must have been a salıne playa lake (McCullough. 1977)

The abundance of intradolomicrites show that much of the original sediment has been reworked and redeposited In the completely dolomitic beds of the middle member, clasts derived from dolomitic muds can not be distınguished from micritic clasts dolomitized after deposition. but it is believed that the clasts were generally if

high C Negatıve print of a thın section of a small chert nodule The dark rım comprises sılıca spherules that decrease in quantity and size away from the nodule Rootlets and other voids are well-preserved in the nodule, and one silicified rootlet (the long vertical tube at center right) extends into the dolomite, demonstratıng preferential sılicification of voids Cove Mountain Member, Cove Mountain 1-mm scale D Chert nodule with grey gradational boundaries except for the poorly understood sharp-edged dolomite embayment at bottom center This chert preserved countless faint rootlets and two orthostriotubules (burrows filled with debris from the same bed and showing watchglass structure, Brewer, 1964) 5-mm scale E Plane light photo of a chert-dolomite boundary like that in Fig 6C The dolomite is to the right. dense, dark, and almost atextural, and it contains light spherules of silıca that incredse in size and number toward the chert Cove Mountain Member, Ferron Mountain Scale is $02 \mathrm{~mm} F$ Negative print of pyrite-rich chert-dolomite boundary Pyrite here is white The dolomite is atextural, but the chert (on the left) preserves intraclasts The grey areas within the pyrite zone and just outside it are hematite-rich dolomite Musını Peak Member, Ephraım Canyon 2-mm scale G Thin section of edge of nodule in Fig 6B Atextural white dolomite is to the right, chert at left preserves the grumelous fabric of the original limestone The boundary here is quite sharp, but slightly feathered The clasts in the chert are typical of the small round micrite peloids that compose many of the limestones They are indistinct where contıguous, but they are made more obvious by the characteristic stellate interpartıcle voids (here tilled with chert) as discussed by Freytet (1973) $02-\mathrm{mm}$ scale, Cove Mountan Member. Cove Mountain 
not always completely dolomitized prior to reworking. In mixed dolomite-calcite beds (see Fig. 2), the lack of alteratıon of calcareous clasts next to dolomitized clasts show that the dolomitized clasts were dolomitized before erosion The flatness of the Flagstaff bedding, the lack of channels and other features indicative of deep erosion. the probable formation of clasts by mudcracking. and the clasts' moderate softness during redeposition (as demonstrated by their generally moderate deformation) together suggest that the original muds were not buried before clast production, and therefore make it probable that dolomitization occurred very early and at the surface Analogies may be drawn with syngenetic tidal-flat and supratidal dolomites described by Friedman and Sanders (1967, p 308 ff.). The transitional zones of thinly interbedded dolostones and limestones above and below the completely dolomitized section and the associated evidence for extreme desiccation and inhospitable water chemistry during middle member deposition argue for intensification of the conditions causing surficial dolomitization at other times rather than a switch to pervasive late-stage dolomitization.

As regards the method of dolomitization, the intense evaporation indicated suggests dolomitization by evaporative pumping of water through the mudflats during periods of exposure in the manner described by Hsu and Siegenthaler (1969). although there is no specific supporting evidence. This model was applied by Wolfbauer and Surdam (1974) and Surdam and Wolfbauer (1975) to the Green River lacustrıne dolomites. Major dolomitization by reflux of brines or infiltration of low $\mathrm{pH}$ rain water can not be ruled out, but as Hsu and Siegenthaler point out they are slow and self-inhibiting processes. Bissell and Chilingar (1962) suggest that intense solar heating of brine-pan mudflats may ard dolomitization in playas

The primary limestones were probably precipitated as a matter of course in the main part of the lake and on the margins during periods of high water. Ostracode-rich limestones may record high water levels, if perıds of increased rainfall and (or) decreased evaporation increased freshness and therefore caused ostracode blooms Regular precipitation in the shallow lake would have shifted the lake around its flat basin, thereby exposing its former deposits to dewatering and dolomitization

\section{The Musinıa Peak Member}

The uppermost member of the Flagstaff begins with the return of gastropods to the lake and the slightly earlier but intımately associated recurrence of slightly calcareous dolostones Together with the reexpansion of the lake as shown by basın-wide transgressions over middle member shorelines, this demonstrates a reduction in evaporation and (or) increase in rainfall and a general freshening of the lake (as suggested by Gill, 1950; contra La Rocque, 1960) The carbonates and shales are in many ways intermediate in character between those of the lowest and middle members Innumerable mudcracks indicate ephemeral surface waters The Musinia Peak Member is rich in calcilutıte "mudrocks" Its dolostones are fine graıned and 
TABLE II

Description, distribution and interpretation of Flagstaff Cherts

\begin{tabular}{cll}
\hline Upper Member & $\begin{array}{l}\text { Thin but extensive beds; } \frac{1}{2} \text { silica, } \frac{1}{2} \text { calcite, } \\
\text { finely and pervasively but not fully silicified, } \\
\text { onginal himestone fabric preserved }\end{array}$ & $\begin{array}{l}\text { Cementation and replace- } \\
\text { ment at top of water } \\
\text { table }\end{array}$ \\
$\begin{array}{c}\text { Middle Member } \\
\text { Lower half }\end{array}$ & $\begin{array}{l}10-5000 \mathrm{~cm}^{3} \text { scattered nodules, } 100 \% \text { silica, } \\
\text { onginal limestone fabric preserved, } \\
\text { gradational into surrounding dolomitized limestone }\end{array}$ & $\begin{array}{l}\text { Replacement of lime- } \\
\text { stone before dolomitiza- } \\
\text { tron, in locally low-pH } \\
\text { groundwater }\end{array}$ \\
& $\begin{array}{l}\text { restncted to specific horizons, no pnor fabrics } \\
\text { On one horizon, nodules are large mudcrack fillings }\end{array}$ & $\begin{array}{l}\text { Direct precipitation of } \\
\text { gel from lake water }\end{array}$ \\
$\begin{array}{c}\text { Lower Member } \\
\text { Upper half }\end{array}$ & $\begin{array}{l}\text { Rare, }<8 \mathrm{~mm}^{3} \text { spherules and linings in largest voids } \\
\text { No pnor fabnc }\end{array}$ & $\begin{array}{l}\text { Late vold filling (pH or } \\
\text { vapor pressure in voids) }\end{array}$ \\
lower half & No chert & \\
\hline
\end{tabular}

homogeneous, are largely platy, and commonly show solution features Calichification features are more common than paludine ones and there are many thin but extensive beds of chert. Increased development of stream and pond deposits during perıods of withdrawal of the lake (documented by Gill, 1950) make this environment more like a semyek.

\section{FORMATION OF THE CHERT}

The descriptions and distribution of the various types of chert found in the Flagstaff are summanzed in Table II.

\section{Voud-controlled chert of the lowest member}

The basal Flagstaff is free of chert. At Cove Mountain, the lowest chert occurs at $95 \mathrm{~m}$ above the base and the remainder of the Ferron Mountain Member contains only a very small amount. The first cherts form $<8 \mathrm{~mm}^{3}$ spheres and crystal aggregates in the largest voids in rootlet moulds and where intergranular micritic matrix has been dissolved in dolomitized rocks. These spheres rarely fill the voids. Chert becomes more diverse and abundant toward the top of the member, where it is present as larger and more complex vold fillings in the form of spheres, crystal tubes and void linings (cutans; terms from Brewer, 1964) The volds include: (1) rootlet moulds; (2) vugs in dolomitized rocks; (3) interparticle voids between small, squashed, 
and indistınct pellet-lıke intraclasts (the stellate packıng volds of Freytet, 1973, or the orthovoids of Brewer, 1964), (4) irregular non-ıntergranular vugs like shrinkage pores (Fischer, 1964; Brewer's orthovughs), and (5) cavities inside or below shells and shell moulds Concomitant with the increase in chert is additional precipitation in voids that are smaller and farther from the main network of volds. vugs and channels, i.e. associated with less groundwater movement. Much of this chert is clear and pale blue

Thus the chert of the lowest member is characterized by being precipitated as spheres and cutans (linings) in voids, especially in interconnected volds that were probably major conduits of groundwater The spheres probably grew slowly by nucleation as saturated ground water moved past, but chert linıngs suggest a more sudden and widespread change in the pore water. The presence of some chert in volds caused by solution related to dolomitization implies a mostly post-dolomite age.

\section{Chert horlzons low in the Cove Mountain Member}

Chert is abundant in the middle member Most of it is present as $10-5000 \mathrm{~cm}^{3}$ nodules (specifically "glaebules" of Brewer, 1964), whıch replace lımestones and are unaffected by volds, but some of the earlier middle member chert is different, as shown below

The earlier chert almost completely lacks texture and fabric, and forms discrete, smooth nodules that do not grade into the enclosing carbonate and are spaced out along well-defined horizons Most nodules are approximately spherical, and most seem to rest on surface of erosion or nondeposition, although some horizons lie withın dolostone beds. In several cases, horizons of nodules occur in thin, laminated calcilutite beds that separate two thicker dolomite beds (Fig 6D and E) Compression has bent calcilutite laminations around most nodules, but in a few extreme instances nodules significantly indent one or both of the enclosing dolomite beds (Fig. 6D). Some texturally identical cherts take the form of angular, vertically oriented, downward-pointing wedges These occur in beds of calcilutite and are rammed into the overlying bed (see Fig. 6F).

None of these nodules were formed by replacement of limestone; there are no relict structures and no included dolomite, but only a few rare ostracodes and some empty channels, possibly moulds of root or stem fragments. They show none of the features of silcretes, nor of late-stage vold fillıngs They differ greatly from magadite cherts as described by Eugster (1969) and in any case the geochemical environment is wrong (Wells et al, 1979) for there is essentially no volcanic material in the Flagstaff (Gill, 1950, Wells. 1977, Dawson, 1978). (Glass shards have been detected in one upper member mudrock; McCullough, 1977 ) The nodules were not transported in their present condition for some are on end and all are large yet surrounded by fine-grained beds At least some can not be post-depositional, formed 
by water moving along bedding planes or joints, because some horizons occur in the middle of unbroken dolomite beds (Fig 6C)

Given the absence of alternative explanations, these nodules must be primary syn-depositıonal features, formed from an inorganically precipitated silica gel of the sorts reported in modern environments by Colinvaux and Goodman (1971), and Peterson and Von der Borch (1965) (see comments on inorganic lacustrine cherts by Wheeler and Textoris, 1978) The wedge-shaped nodules are conclusive on this point: their shape is identical to micrite-filled mudcracks in calcilutites at the base of massive micrites (compare Fig 6B and F) and therefore they are interpreted as mudcracks filled by the inflow, inwash, or precipitation of silica gel Their add detached appearance (see also Fig. 6C) and their indenting the beds above and below are due to post-burial compaction of the surrounding calcilutite after hardening of the chert This origin also accounts for their presence in horizons. for precipitation of colloidal gel would be a lake-wide event triggered by a mechanism like a sharp drop in the lake's $\mathrm{pH}$ by rain after a build-up of silica This would be equally true of the more common round nodules, in which instance the gel may have been precipitated as nodules or as a soft aqueous layer that was later reworked into balls Balls of aqueous gel would have been soft and light and could easily have been rounded by rolling or shaping by currents Such nodules would also have discrete surfaces (non-gradational boundaries) and the chert would be atextural except for any included debris (see Biggs, 1957) After dewaterıng, hardening and burial, the round nodules might sink or be compressed into underlying wet carbonate muds.

\section{Limestone-replacing chert nodules of the middle member}

Through the remainder of the middle member, the chert is nodular and formed by silicification of calcareous sediment prior to dolomitization Replacement by chert prior to dolomitization is shown by the preservation of many features, such as organic material, rootlets, burrows, ostracode carapaces, oolites, all types of desiccatıon cracks, peloids, laminations, and bedding, that are largely obliterated in the surrounding white aphanitic dolostone (Fig 7, see also Pittman, 1959)

The cherts are all alpha-quartz, as determıned by X-ray diffraction analysıs usıng the methods of Jensen et al. (1957), and have inherıted approximately the same kınds and amounts of impurities as found in the surrounding dolostones Some of the organic-rich cherts are also rich in pyrite and a few cherts have extremely large quantities of ostracodes, testıfying to occasional ostracodal (and algal?) blooms. Most of the chert nodules are grey to light brown and are surrounded by a rim of fine pyrite, but others are greenısh-grey (from pyrıte and reduced iron), pink to red (from hematite), or brownish-black (from organic material) Most organic-rich nodules are internally cracked, and the cracks are filled with a clear pale blue chert identical to that filling voids in the lower member. This clear blue chert etches preferentially when bolled in $\mathrm{NaOH}$, suggestıng (according to Pelto's 1956 work on 
similar cherts) that it is etther composed of smaller crystals or it is less ordered or possibly contains more water It is cryptocrystalline and is free of the impurities present in the limestone-replacing chert and dolostone. It might be opal or 2-d-crystobalite, but this is not well supported by X-ray diffraction data

Many of the nodules appear to be marked by a chert "front", a farly sharp line delimitıng the dolomite and the chert that is frequently dark due to a concentration of pyrite ( $F_{1 g} 7 \mathrm{~A}$ and F) Some fronts are very sharp (e.g Fig 7G and D), but most are in fact gradational across $03-15 \mathrm{~cm}\left(\mathrm{~F}_{1 \mathrm{~g}} 7 \mathrm{~B}-\mathrm{E}\right)$, as can be easily checked by scoring polished slabs with a knife Very poorly preserved in the zone are ostracodes. shrinkage pores and rootlets.

The partly silicified gradational zones give evidence that: (1) the growth of the nodules appears to have been halted by dolomitization; and (2) there was a specific sequence of silicification and nodule growth Well-preserved textures immediately inside most nodules argue against continued silicification after destruction of the fabric of the sediment by dolomitization. The general lack of alteration of dolomitic intraclasts in the few middle and upper member cherts that contain them suggests that silica did not replace dolomite as easily as calcite The intraclasts in one such chert are riddled with silica spherules (Fig $6 \mathrm{H}$ ) that in no way preserve the texture or fabric of the dolomite. The apparent difficulty of silicifying dolomite suggests that dolomitization generally arrested silicification and nodule growth

The increasing concentration of silica toward symmetrical nodules - the increase in size and abundance of the spherules as shown in Fig $7 \mathrm{C}$-suggests that silica had diffused toward the nodule from all directions and was progressively more likely to precipitate as it approached. The relative breadth of the nodules suggests that much of the silica approached the growing nodule laterally, through thin surface layers of calcitic sediments (see Hsu, 1976) Ostracodes and rootlet moulds seem to have been preferred sites of silica deposition insofar as they became fully silicified well outside the zone of general silicification (Fig. 7c) Most such voids were lined with clear blue chert before being filled with crystals. Initial silicification of the calcite away from the nodule resulted in a very patchy or fine and irregular texture that gave the boundary either a mottled or a feathered appearance. As silıcification continued, the entire fabric became preserved in chert and the transitional zone expanded in front of the growing nodule The nodules probably began forming because, in an environment as alkalıne as water in a lıme mud, nodular chert is more stable than dispersed silica. The detalled replacement of limestone occurred because areas of lower $\mathrm{pH}$ that would favor silica precipitation would at the same time favor dissolution of calcite (Pittman, 1959)

Silicification must have been very early Not only did it precede dolomitization. which was itself a very early event, but also in the cases where the nodule is cut by dolomite-filled mudcracks it demonstrably occurred before mudcrack formation and burıal ( $F_{1} g$ 5A) In instances where the mudcracks skirt the nodule or where the mudcrack is filled with silica or silicified debris, tımıng is less certain (but see Harris, 1958) 
In short, the proposed method of growth and the occasionally seen partial silicification of dolomite at the edges of nodules or in mudcracks suggest the following history of chert formation-

(1) Amorphous (colloidal) or very fine crystallıne silica was precıpıtated and (or) deposited from the lake waters and became finely dispersed through the calcareous sediment

(2) However, it became re-dissolved when the $\mathrm{pH}$ of the pore waters rose after losing contact with the atmosphere (Graf, 1960)

(3) Non-uniform pH created horizontal diffusion gradients that pulled silica into areas of lower $\mathrm{pH}$ to form nodules by local fine-scale replacement of calcite. Sometimes before and sometımes after this stage mudcracks were formed, perhaps due to a lacustrine regression.

(4) Then the mudcracks were filled and dolomitization occurred, in either order

(5) Silicification, which was slow relative to dolomitızation, continued briefly and then stopped

(6) If opaline at first, the silica was soon converted to alpha-quartz by the alkaline groundwater.

\section{Silicified beds of the Musinia Peak Member}

In contrast to the pure chert nodules and void fillings of other members, in the uppermost member whole beds of limestones are silicified (Figs. $4 \mathrm{C}$ and 6G). The silica is dispersed through the bed, although it does not completely replace the carbonate The crust-like beds are thin (several centimeters) but extend for great distances. The chert preserves primary fabric in dolomitized limestones and is therefore pre-dolomitization, but local partial silicification of dolomitized limestone shows that silıcification occasionally contınued afterwards as well Ostracodes, snails and voids were preferentially silicified. Most of the beds are mudcracked and the mudcrack-fillıng micritıc and biogenıc debris is evenly silıcified (some clasts show very faint and diffuse edges) The main part of the bed, most commonly an ostracodal micrite, is at least $40 \%$ finely dispersed silica, thus the rock will react equally to either hot $\mathrm{NaOH}$ or $\mathrm{HCl}$, although neither etching is patchy or deep. The yellowish-white weathered surfaces, however, do not react with $\mathrm{HCl}$ - the carbonate has all been leached from the immediate surface durıng weathering

Vertical movement of silica to a specific level seems required to silicify such thin but extensive units, suggesting that the top of the water table was involved Preferential silicification of fossil, desiccation, and intergranular voids implicates moving water

\section{Iron and chert}

At some tıme during silicification, iron must have been mobilized in large quantıtıes, for many chert/carbonate boundarıes are marked by pyrite and hematite 
bands and mudcrack fillings, particularly in upper member cherts, can contain up to $35 \%$ hematite that is pseudomorphous after pyrite $(\mathrm{F} i \mathrm{~g}$. $7 \mathrm{~F})$. When in situ, the pyrite is generally clustered right inside the chert/dolomite boundary, whereas the pseudomorphous hematite lies just outsıde. Both sharply decrease away from the boundary, in size and in numbers of crystals Clearly, pyrite formed at the boundary, but it has only escaped oxidation inside the impermeable chert It may have formed because of the release and expulsion of iron during the silicification of iron-rich carbonate (see McCullough, 1977, p.35 ff, for discussion of iron content of Flagstaff dolomites). The decrease in pyrite inward and outward from the boundary would therefore reflect precipitation at the boundary, decreasing outward, and also increased precipıtation as the nodule expands, because its surface area increases less than the volume of calcite replaced Swett (1965) noted similar expulsion of iron from silicified oolites.

\section{GEOCHEMISTRY OF THE CHERT}

Source of the sllica

The most likely source for the silica appears to have been the sandstones surrounding the lake beds. Using criteria from Bourcart et al. (1933), analysis of - (1) Flagstaff sandstones; (2) North Horn sandstones collected by Birsa, and (3) remarks in the literature (e.g. Cadigan, 1972a, pp.60-61, 1972b, p.62, Peterson, 1976) shows that minor solution features on quartz grains are widespread in this basin Some feldspar grans also show solution features. Generally, the sandstones are too mature for heavy minerals to be a source of much silica (McCullough, 1977, p.45 ff). (Processes of dissolution and calcitization of silicates are described by Millot and others, 1979 ) Grasslands around lakes can be important in preparing soluble silica, for Jones (in Shepherd, 1972, p.82) notes that they annually convert $20 \mathrm{~g} \mathrm{~m}^{-2}$ of silica into tiny opal phytoliths, although grass is rare before the Miocene

Intermediate sources of slica withın the lake are considered unlıkely, even though detrital quartz is a common source of silıca in many lakes (Bourcart et al., 1933, see also Cayeux, 1929) and for many silcretes (Thiry, 1981), for too little sandstone was deposited in Lake Flagstaff The importance of alrborne slica dust is unknown, although none was observed. In the middle member, possible clay diagenesis of mixed-layer clays to illite in the middle member may have freed some silica (see McCullough, 1977, for distribution of clays). Montmorillonite can change into illte (Weaver, 1958), acquiring $\mathrm{K}_{x} \mathrm{Al}_{x+\imath}$ and releasing (Mg, $\mathrm{Ca}$ ), and $\mathrm{Si}_{1}$ and a minor amount of exchangeable cations (Tome, 1962, Berner, 1971) Lastly, suttable sil 1ceous fossils are not known from the lake beds. Therefore, most of the silica seems to have come from the dissolution of the detrital quartz, chert, and feldspar in both the clastic-rich Indianola, North Horn and Colton Formations within the basin and the Mesozoic beds in the uplifts nearby. 


\section{Transportation into the lake}

Silica probably entered the lake in streams and groundwater in solution or as colloids rather than as detrital grains or phytoliths, for epiclastics were rarely transported across the flat lake plain. Groundwater was probably more important. because its $\mathrm{pH}$ would have been higher and it could have carried much more silica. Groundwater in limestone, when closed to the atmosphere, has a pH of 99 (Graf. 1960), whereas the $\mathrm{pH}$ of Flagstaff streams was probably below $9.0[\mathrm{pH}=84$ when water is in equilibrium with air and calcite (Garrels, 1960, p 52) or between 7 and 8 if typical of streams in arid regions (Krauskopf, 1967, p 35)]. Below a pH of 9.0. sılica forms relatively insoluble and $\mathrm{pH}$-ındependent $\mathrm{H}_{4} \mathrm{~S}_{1} \mathrm{O}_{4}$ In this range, $\mathrm{K}_{\iota \mathrm{p}}$ of amorphous s1lica is 120 ppm and $\mathrm{K}_{\mathrm{sp}}$ of alpha-quartz is 16 ppm (Berner, 1971) The normal range of silica in rivers is 3 to about 120 ppm including colloids (Krauskopf, 1959; Berner, 1971) or 10-60 ppm excluding colloids (Krauskopf, 1967). Livingstone (1963) gives an average of $21 \mathrm{ppm}$. On the other hand, above a $\mathrm{pH}$ of 90 , silicic acid conizes to $\mathrm{H}_{3} \mathrm{~S}_{1} \mathrm{O}_{4}^{-}$and $\mathrm{H}_{2} \mathrm{~S}_{1} \mathrm{O}_{4}^{2-}$ (Krauskopf, 1959), and solubility is greatly increased and becomes dependent on $\mathrm{pH}$ Jones et al (1967) indicate that the activity of $\mathrm{H}_{3} \mathrm{SiO}_{4}^{-}$at $\mathrm{pH}=9.9$ will be 450 ppm For more values, see Fritz and Tardy (1973).

\section{Precipitation of silica}

Once in the lake, sllica would have been concentrated either by evaporative concentration or by an increase in solubility because of a rising $\mathrm{pH}$ At surface temperatures, silica may be brought out of solution by organisms, falling $\mathrm{pH}$. increasing salınıty, evaporatıve concentration, adsorption (by clays, volcanıc glass and hydrous oxides), or by a decrease in pressure (Krauskopf, 1959; Jones et al , 1967, Iler, 1978; and Marshall and Waramkowsk1, 1980). Colloidal silica is precipitated and coagulated into a gel by evaporative concentration, cooling, or addition of electrolytes. Anything that speeds precipitation promotes formation of a gel rather than individual colloids (Krauskopf, 1959). Due to kinetics, high levels of supersaturation may be reached when the water is not in contact with silica or silicate muds (Jones et al , 1967) and low in sodıum (precluding magadite formation), as may have been the case in clay-poor and volcanically unaffected Lake Flagstaff. Silica supersaturation due to low clay content has been observed in the Dead Sea by Amit (1968).

Uptake of silica by organisms is unlikely to have been important withın Lake Flagstaff because no fossils of silica-requiring organisms have been found. If any were present, the most likely is Equisetum, the horsetall. Freshwater diatoms in particular do not seem to have evolved unt1l the Oligocene (Bold and Wynne, 1978, p.397) or become common unt1l the Miocene (see comments by Lohman, 1964), whereas today they completely control lacustrine silica cycles (Hecky and Kilham, 
1973; Wetzel, 1975, pp.278-286). Therefore, sllica cycles in modern lakes may not be analogous to Lake Flagstaff and other ancient lakes (see comments by Wheeler and Textoris, 1978).

Complexing and adsorption are of minor importance in the silica cycle (Krauskopf, 1959). Silica may be taken up in the diagenesis of clays (Weaver, 1958) and, if cations are abundant, silicates may form (Eugster and Chou, 1973), partıcularly sepiolıte (Hardie and Eugster, 1970), magadute (Hay, 1968; Eugster, 1969), and zeolites (Surdam and Eugster, 1976; Eugster and Hardie. 1978). None has been detected in the Flagstaff

Reduction of pressure might just be significant in the precipitation of silica in volds, but evaporation caused by relatively low vapor pressure is probably more important.

In the absence of silica-precipitatıng organisms, fluctuation of the $\mathrm{pH}$ around 90 is a likely major control of silica. Such fluctuations can occur in many ways Evaporative concentration of bicarbonate-rich waters can raise the $\mathrm{pH}$ (above 12 if $\mathrm{Na}$ is absent) as can $\mathrm{CO}_{2}$ degassing by a warming of the lake and by $\mathrm{CO}_{2}$ removal during photosynthesis (Hutchinson, 1957). Photosynthesis can raise the $\mathrm{pH}$ above 10 on a seasonal or even daily basis if the lake is normally quite alkaline (Peterson and Von der Borch, 1965) On the other hand, increased $\mathrm{CO}_{2}$ will lower the $\mathrm{pH}$ The major source of $\mathrm{CO}_{2}$ in highly alkalıne lakes is organic decomposition (Peterson and Von der Borch, 1965), but it is also produced durıng dark photosynthesis and by animal respiration, and it is taken up from the atmosphere when the lake cools. Although $\mathrm{pH}$ fluctuation is a very attractive mechanism, modelling of the chemistry of Lake Flagstaff as it changed from a calcite-precipitating lake to a dolomitizing and gypsum-precipitating lake suggests that the $\mathrm{pH}$ would have fallen from about 84 to 8.0 or less, makıng fluctuation of the lake water above 9.0 less likely (Wells et al, 1979)

Slow equlibration between substantially different waters can precipitate silica through pH-dependent reactions. The most commonly cited lacustrine example of this occurs when approxımately neutral fresh floodwaters flow out over a salıne-alkalıne lake, creating chemical stratıfication instead of mixıng with 1t, and dilution, lowering of $\mathrm{pH}$, and increasing of activity coefficients along the chemocline precipitate silica ("freshwater flooding", Eugster, 1969). Coincidence of the thermocline and the chemocline in deep and more permanently stratıfied saline lakes may provide a sharp enough boundary to allow a simlar $\mathrm{pH}$ equlibration and silica precipitation In many alkaline lakes, another boundary where silica could be precipitated is present at or just above the sediment-water interface between acid to neutral waters enriched in decomposition-derived $\mathrm{CO}_{2}$ and the overlying alkalıne lake water (Peterson and Von der Borch, 1965) Mixing of brines and freshwater may precipitate silica within the sediments (Knauth, 1979), and silica crusts could be formed by vertical mixing of alkaline groundwater and infiltratıng acidic or neutral rainwater. 
In the Flagstaff, therefore, it seems likely that the absence or scarcity of such potential silica users, adsorbers, and nuclei as diatoms, volcanic glass, and clay would have allowed considerable evaporative concentration of dissolved silica. Assuming a steady $\mathrm{SO}_{4}^{2-}$ buld-up (Cloke and Wells, unpubl.), pH fluctuation of the lake water around 9.0 does not seem likely to have caused initial silica precipitation in the Flagstaff, except possible for the lowermost middle member cherts. Therefore, the most important cause of initial silica precipitation in Lake Flagstaff would seem to have been evaporative concentration untıl precipitation occurred Local variability in groundwater $\mathrm{pH}$ was, however, undoubtedly critical in subsequent replacement of calcitic sediments and nodule growth.

\section{SPECULATIVE PALEOLIMNOLOGY AND CONCLUSIONS}

Lake Flagstaff was created by ponding between the old Sevier orogenic belt in the west and early Tertıary uplıfts in the east Gradually, alluvial fans, alluvial plains, streams, and ponds became inundated untıl a very large NE-SW-oriented lake was formed. This study suggests that the lake was in a very flat basin and was shallow and weedy throughout. Lake level apparently fluctuated constantly in response to rainfall and evaporation, causing exposure or flooding of very large areas The intermittently inundated carbonate mudflats were nonclastic and probably barren to weedy, and they were crossed by a few small streams. Exposure of the flats caused extensıve mudcracking; prolonged exposure allowed initial soll-forming processes and calichification to create some distinctive features such as the polyphased nodules and recrystallization fabrics of Freytet (1973). Flash floods, wind tides and wave action (particularly during reexpansion of the lake when the fetch increased and wave-baffling vegetation was drowned) could have created erosion surfaces, removed stıff micrite fragments, redeposited them as intraclasts, and filled mudcracks with detritus. Frequent erosion and shifting of the sediment may have kept the lake floor flat

The lake was probably always quite productive because its shallowness created a very wide littoral zone and because very little nitrogen and phosphorus are needed to make shallow lakes extremely productıve (Vollenweider. 1968). Nevertheless, the relative rarity of pyrite and organic-rich limestones suggests that the lake was rarely eutrophic and that nutrients, once buried, were not often returned to the lake (thereby limiting total productivity; see Mortımer, 1941) The increased weediness of the earliest lake was probably a significant and to animals because the aquatic macrophytes in such a lake are important as pioneers, recolonizing recently inundated floodplains after a regression/reexpansion cycle They would have allowed trophic diversity over what would have otherwise been a uniform and featureless lake floor by providing food, habitat, and hiding places for colonizing animals (McLachlan, 1975), and they would have served as temperature buffers for fish (McCarraher, 1970). Lake Flagstaff almost certainly had very 1rregular temperatures 
(which normally affects the composition of the fauna) because shallow lakes are subject to frequent and rapid mixing and to direct solar heatıng of the sediment and because they have great sediment-water and air-water interface areas relative to their volumes. Mollusks and ostracodes were abundant and fish, reptiles and birds were probably common as well (La Rocque, 1960; Zawiskı, in prep )

At first, Lake Flagstaff was probably a normal, fresh, moderately alkalıne. $\mathrm{Ca}-\mathrm{Mg}-\mathrm{HCO}_{3}$-rıch, hardwater, semyek-lıke lake, distınguished mainly by its shallowness and its fluctuating water levels. The importance of dolomitization, calıchification, and gypsum in the middle member argue for a gradual change into a salıne playa lake with high magnesium and sulphate concentrations under an arid climate with high temperatures, increased rates of evaporation, and (Or) decreased rainfall (McCullough, 1977, Wells et al., 1979). The last phase was intermediate it has extensive dolomite and desiccation features but it also has snals and limestones and lacks gypsum. These factors indicate a drop in arıdity.

These three climate-controlled lake phases probably correlate with mid to late Paleocene low temperatures, early Eocene high temperatures, and the post-Early Eocene slightly less warm period, as deduced from vegetational evidence (Dorf, 1970, figs. 3 and 5: Hickey, 1980) and mammal abundance and diversity (Gingerıch et al, 1980). (It is interesting that synchronous climatic changes caused significant changes in silcrete and calcrete formation in the Parıs basın; Thiry, 1981.)

The small amount of vold-filling chert in the lowest member suggests limited input of silica and late (post-dolomitization) precipitation in areas of lowest vapor pressure and most groundwater movement Evaporative concentration because of lower pore pressures in the larger volds may have allowed supersaturation and slow growth of chert spheres. Void linings, in contrast, may have formed more suddenly, perhaps by $\mathrm{pH}$ changes related to $\mathrm{CO}_{2}$ changes caused by occasional contact between pore waters and the atmosphere or rain water. Subsequently, evaporative concentration of silica in the lake under an arid climate allowed it to build up to a point where it could precipitate directly from the lake as a gel, possibly as a result of $\mathrm{pH}$ fluctuations above and below 9 prior to the buld-up of dissolved sulphate This resulted in several horizons of atextural chert nodules and silica-filled mudcracks. The following change to nodules of more scattered and limestone-replacing chert probably represents regular precipitation and remobilization of dispersed amorphous or finely crystalline silica both before and after the time of mudcrack formation. Migration of silica into areas of lower $\mathrm{pH}$ and replacement of calcite must have occasionally begun at the time of deposition, prior to regression and exposure, as soon as the pore water locally lost contact with the atmosphere and re-equilibrated with calcite at a higher $\mathrm{pH}$. Dolomitization seems to have almost entirely arrested the growth of chert nodules, and in the few exceptions where silicification continued briefly, replacement of dolomite was destructıve. This may be due to fallure of a $\mathrm{pH}$-attuned process of calcite dissolution and silica replacement. The role of $\mathrm{pH}$ is suggested by Lippmann's (1973) attribution of some dolomitization to increased 
carbonate ion activity and by Chilıngar's (1956) report of a simılar pH-related $\mathrm{Mg}: \mathrm{S}_{\mathbf{l}}$ antipathy in carbonate rocks

Later freshenıng of the lake due to the return of a less and climate was not accompanied by lower silica levels and a return to silica formation as seen in the lowest member. Instead, silicification became even more prevalent Chert most probably formed at the top of the water table, resulting in thin but extensive silicification Evaporative pumping of water to a specific horizon where silica is deposited and subsequent concentration and precipitation of silica without involvement of $\mathrm{pH}$ changes can also explain the pervasive rather than completely replacive silicification, but some silicification from equilibration between siliceous alkaline groundwater and more acidic infiltratıng rain water or lake water is possible The groundwater may have been buried lake water, but more likely it was water moving under the mudflats from the margin of the basin, for the progressive increase in chert during the lake's existence and the apparently limited silica sources within the lake suggest progressively increasing influx of silica in comparatively alkaline and siliceous rock-equilibrated groundwater, relative to surficial runoff and streams

In short, chert was formed in this lake by (1) comparatively late vold filling after dolomitization and burial (controlled by vapor pressure in pores and/or pore water $\mathrm{pH}$ ); (2) primary inorganic precipitation as a gel (perhaps controlled by $\mathrm{pH}$ fluctuations in the lake), (3) syngenetic to very-early-burial complete replacement of calcite, forming nodules, (with silica initially precipitated by evaporative concentration in the lake, and later remobilized by inhomogeneities in $\mathrm{pH}$ of water in the sediment); and (4) similarly early, partial yet pervasive, silcrete-like silicification of thin beds of limestone over wide areas (possibly caused by evaporation at the top of the water table)

Decades ago, researchers concerned with the origin of chert would pit their findings against one another as though there were a single solution to "the chert problem". Many different origins are now accepted (see Shepherd, 1972, preface and ch 3) and a great variety of parageneses have been documented (Dapples, 1979), but the finding of four main modes of formation in one lake deposit demonstrates nicely why this approach led to such a lengthy and misdirected debate. This report also demonstrates that as far as organic versus inorganic control of silica cycles in lakes, the present is not the key to the past.

\section{ACKNOWLEDGEMENTS}

First and foremost, I would like to acknowledge Lon McCullough. By rights, he should be a co-author on this paper-we shared the field work that led to our M Sc. theses, and we freely traded ideas and data during the duration of our complementary and intertwined projects. I regret that Lon feels he cannot accept co-authorship without workıng on this manuscript, which he has been unable to do owing to the pressures of work 
This research was done at Ohio State University under the guidance of Drs. K.O. Stanley and J.W. Collinson and has been supported in one way or another by Sigma $\mathrm{X}_{\mathrm{I}}$ and both the Department of Geology and Mineralogy and the Institute of Polar Studies at Ohıo State. R S Dawson assisted in the field work. I would also like to thank, in alphabetıcal order, D. Bell. Dr. P.L Cloke, D. Cooke, L J Cox, Dr. G. Faure, J. Franklın, Dr. S. Jacobsen, M. McCullough. Dr. G. McKenzıe, Dr. C.H Summerson, C Vavra and R. Wilkınson for their assistance Dr. M.P Weiss and two anonymous reviewers made some valuable comments on the manuscript.

\section{APPENDIX}

For those concerned with the detailed stratigraphy of the Flagstaff Formation, further explanation will be required for Fig 1 The map differs from Gunderson and Gillıland (1967) because they included thicknesses of the whole Flagstaff, including supralittoral facies, left after erosion, whereas 1 used complete sections of lacustrine facies of the lower member only Differences from Weiss (1969) are due to new correlations of sections

First, the two snall faunas in the fossiliferous lake limestones of Gilliland's Unit B in the Valley Mountains are correlated with the upper half of the lower member, not with the middle member, because of Viviparus trochiformis and Holospira leıdyı in Gillıland's fauna (Gillıland, 1948) (Physa bridgerensis has been extended to the lower Flagstaff by Davis, 1967) and $V$ trochiformis in Lautenschiager's collection from Sweet Creek in the Pavants (Lautenschlager, 1952, p 57, see also La Rocque, 1960, collection 53, snall ranges from La Rocque, 1960) The unfossilıferous, red, supralıttoral sediments of Gillıland's overlyıng Unit $\mathrm{C}$ belong to the middle member and, when other work is considered, no longer require middle Lake Flagstaff to extend west of the Gunnison Plateau

Second, the red, arenaceous, supralittoral "basal Flagstaff' of McGookey (1958) south of Salina Canyon is of middle Flagstaff age by physical tracing (McGookey, 1960) and ostracode evidence (Swain, 1956). whereas the underlying "upper North Horn" 1s lacustrine (McGookey, 1958) and contains lower Flagstaff ostracodes (Swain, in McGookey, 1960). This muscorrelation is a result of the desire of some workers to place a lacustrine unit at the top of the North Horn, following Speiker and Reeside (1925, see also Katherman, 1949) and results in lower member lakes that are too small and middle member lakes that are too big

Third, the eastward increase in age of the base of the lacustrine beds along the Book Cliffs from Thistle (Spieker, 1949, Davis, 1967) and their subsurface correlation to thick "Green River" beds at Soldıer Summit by Ryder et al (1976) demonstrate a lower Flagstaff lake in the Uinta basın Separatıon of lower and upper Flagstaff by Colton sandstones of middle member age (Swain, 1956) again shows the middle member lake to be the smallest. Other less important and less certain detalls may be found in Wells (1977, pp 20-30 and 140-146)

\section{REFERENCES}

Amut, O, 1968 Silica content and silica-clay interactions in the water of the Dead Sea (Israel) Chem Geol, 5 121-129

Armstrong, R L, 1968. Sevier orogenic belt in Nevada and Utah Geol Soc Am Bull, 79 429-458

Berner, R A, 1971 Principles of Chemcal Sedimentology McGraw-Hill, New York, N Y, 240 pp

Bıggs, D L, 1957 Petrography and ongin of Illınoıs nodular cherts Ill Geol Surv Circ, 245

Bissell, H J. and Chilingar, G.V., 1962 Evaporite type dolomite in salt flats of western Utah Sedimentology, $1200-210$. 
Bold, HC and Wynne, MJ, 1978 Introduction to the Algae Prentice-Hall, Englewood Cliffs, N J. $706 \mathrm{pp}$

Bourcart, J, Auzel, M and Michel, J, 1933 Sur l'altération des grames de quartz dans certains calcaıres Soc Géol Fr, C R, 198 197-198

Brewer, R, 1964 Fabric and Mineral Analysis of Solls Wiley, New York, N Y . 470 pp

Cadıgan, RA, 1972a Sedımentary petrology In J H Stewart, FG Poole and R F Wilson (Editors), Stratigraphy and Origins of the Chinle Formation and Related Strata in the Colorado Plateau Region U S Geol Surv, Prof Pap, 690 56-62

Cadıgan, RA, 1972b Sedımentary petrology In J H Stewart, FG Poole and R F Wilson (Edıtors), Stratigraphy and Origins of the Triassic Moenkopı Formation and Related Strata in the Colorado Plateau Region U S Geol Surv, Prof Pap, 691 60-64

Cayeux, L, 1929 Les roches sédımentaıres de Frances-Roches silıceuses Mém Carte Geol Détaıllee de France, $774 \mathrm{pp}$

Chilingar, G V , 1956 Distribution and abundance of chert and flint as related to the $\mathrm{Ca} / \mathrm{Mg}$ ratio of lımestones Geol Soc Am Bull, 67 1559-1562

Chilıngar, G V Zenger, D H, Bissell, H J. and Wolf, K K, 1979 Dolomites and dolomitization In G Larsen and G V Chilıngar (Editors), Diagenesis in Sedıments and Sedimentary Rocks (Developments in Sedımentology, 25A) Elsevier, Amsterdam, pP 423-536

Colinvaux, P.A and Goodman, D, 1971 Recent silica gel from salıne lake in Galapagos Islands Bull Am Assoc Pet Geol, 55 333-334 (abstract)

Dapples, EC.. 1979 Silica as an agent in diagenesis In G Larsen and G V Chilingar (Editors). Diageniesıs in Sedıments and Sedımentary Rocks (Developments in Sedımentology, 25A) Elsevier. Amsterdam, pp 99-142

Davis. J W, 1967 Stratigraphy of the Flagstaff Limestone, southeastern Utah County, Utah Unpubl M S Thesis, Ohio State University

Dawson, R S , 1978 Strontium 1sotope geology of a section of the Flagstaff Limestone, central Utah Unpubl MS Thesis, Ohıo State University, 152 pp

Dorf, E, 1970 Paleobotanical evidence of Mesozorc and Cenozoic climatic changes North Am. Paleontol Convention, Chicago, 1969, Proc, D (Paleoclimatology), pp. 323-346

Dussart, B, 1976 Lımnologie l'Étude des Eaux Contınentales Gauthır-Vıllars, Pans, 678 pp

Eugster, H -P., 1969 Inorganic bedded cherts from the Magadı area, Kenya. Contrib Mineral Petrol , 22 $1-31$

Eugster, H-P and I-Ming Chou, 1973. The depositional environments of Precambnan banded Iron formations Econ Geol, 68 1144-1168

Eugster, H -P and Hardie, L A, 1975. Sedimentation in an ancient playa-lake complex the Wilkens Peak Member of the Green Ruver Formation of Wyoming Geol Soc. Am Bull, 86 319-334

Eugster, H -P and Hardıe, L A, 1978 Salıne lakes In A Lerman (Edıtor), Lakes-Chemıstry, Geology, Physıcs Springer. New York, N Y

Fischer, A G, 1964 The Lofer cyclothems of the Alpine Triassic Kansas Geol Surv Bull . 169 107-149

Freytet, P, 1973 Petrography and paleoenvironment of contınental carbonate deposits with particular reference to the Upper Cretaceous and Lower Eocene of Languedoc (southern France) Sediment Geol, $1025-60$

Friedman, G.M and Sanders, JE, 1967 Ongin and occurrence of dolostones In G V Chilıngar, H J Bissell and R W Fairbridge (Edıtors), Carbonate Rocks (Developments in Sedımentology. 9A) Elsevier, Amsterdam, pp 267-348

Frıtz, B and Tardy, Y, 1973 Étude thermodynamıque du système gibbsite, quartzıte, kaolınıte. gaz carbonıque Scı Géol Bull, Strassbourg, 26: 339-367

Garrels, R M , 1960 Mineral Equilibna Harper and Row, New York, N Y, 284 pp

Garnson, RE and Kennedy, W J, 1977 Ongın of solution seams and flaser structure in Upper Cretaceous chalks of southern England. Sedıment Geol, 19 107-137. 
Gill, J R. 1950 Flagstaff Limestone of the Spring City-Mantı area, San Pete County. Utah Unpubl MS Thesis, Ohio State University, $209 \mathrm{pp}$

Gilliand, W N, 1948 Geology of the Gunnison quadrangle, Utah Unpubl Ph D Diss, Ohıo State University

Gingench, P.D, Rose, K D. and Krause, D W , 1980 Early Cenozoic mammalian faunas of the Clark's Fork Basın-Polecat Bench area, northwestern Wyomıng In P D Gingenich (Editor), Early Cenozoic Paleontology and Stratigraphy of the Bighorn Basın. Wyoming. Univ of Michıgan. Museum of Paleontology. Papers on Paleontology, 24 51-68

Golterman, H L, 1967 Influence of the mud on the chemsstry of the water in relation to productivity In H L Golterman and R S Clymer (Editors), Chemical Environment in the Aquatic Habitat NoordHollandse, Amsterdam, pp 297-313

Graf, D L, 1960 Geochemustry of carbonate sedıments and sedımentary carbonate rocks Ill Geol Surv Circ , 297, 298, 301, 308 and 309

Gunderson, W C and Gilıland, W N, 1967 Stratıgraphic reflections of the Sanpete-Sevier Valley anticlıne of central Utah. Trans N Y Acad Sci, Ser 2, 29. 686-699

Hanley, JH, 1976 Paleosynecology of nonmarıne mollusca from the Green Ruver and Wasatch Formations (Eocene), southwestern Wyoming and northwestern Colorado In R.W Scolt and R R West (Edıtors), Structure and Classification of Paleocommunities Dowden, Hutchinson and Ross, New York, N Y, pp 235-261

Hardie, L A and Eugster, H -P, 1970 The evolution of closed basin brines Miner Soc Am, Spec Pap. $3273-290$

Harris, H D, 1959. Late Mesozoic positive areas in western Utah Bull. Am Assoc Pet Geol, 43 $2636-2652$

Harrıs, L D, 1958 Syngenetic chert in the Middle Ordovician Hardy Creek Limestone of southwest Virginia J Sediment Petrol, 28 205-208

Hay, R L, 1968 Chert and its sodium-silicate precursors in sodium-carbonate lakes of East Africa Contrib Mineral Petrol, 17 255-274

Hecky, R E and Kılham, P, 1973 Diatoms in alkalıne, salıne lakes ecology and geochemical implications Limnol Oceanogr.. 18 53-72

Hıckey, L J, 1980 Paleocene stratigraphy and flora of the Clark's Fork Basin In P.D Gingerich (Editor), Early Cenozoic Paleontology and Stratıgraphy of the Bighorn Basin, Wyoming Univ of Michugan, Museum of Paleontology, Papers on Paleontology, 24 33-49

Hsu, K J, 1976 Paleoceanography of the Mesozoic Alpine Tethys Geol Soc Am., Spec Pap, 170 1-44

Hsu, K J and Siegenthaler, C., 1969 Prelımunary experıments on hydrodynamic movement induced by evaporation and their beanng on the dolomite problem Sedimentology, 12 11-25

Hunt, C B , 1956 Cenozorc geology of the Colorado Plateau U.S Geol. Surv, Prof Pap, 279 1-99

Hutchınson, G E, 1957 Treatıse on Limnology, vol. 1, Wiley, New York, N Y. 1015 pp

Iler, R K, 1978 The Chemustry of Silıca (2nd ed) Wiley, New York, N Y, 866 pp

Jensen, A T . Wohlk, C.J, Drenck, K. and Andersen, E K. 1957 A classıficatıon of Danısh flints etc based on X-ray diffractometry Committee on Alkalı Reactions in Concrete. Danish Nat Inst of Buldıng Research and Acad. Tech Scı, Progress Rep D1

Jones, B F, Retug, S L and Eugster, H -P, 1967 Silıca in alkalı brınes Science, 158 1310-1314

Katherman, V E., 1948 The Flagstaff Limestone on the east front of the Gunnison Plateau of central Utab Unpubl M S Thesis, Ohıo State Unıversity

Knauth, L P., 1979 A model for the origin of chert in limestone. Geology, 7 274-277

Krauskopf, K B , 1959 The geochemistry of silıca in sedımentary environments. In H A Ireland (Editor). Silica in Sedıments Soc Econ Palaeontol Mineral, Spec Publ, 7 4-19

Krauskopf, K B , 1967 Introduction to Geochemstry McGraw-Hıll, New York, N Y, 721 pp

La Rocque, A, 1960 Molluscan fauna of the Flagstaff formation of central Utah Geol Soc Am Mem, $78 \quad 1-100$. 
Lautenschlager, H K, 1952 The geology of the central part of the Pavant Range, Utah Unpubl Ph D Diss, Ohio State University

Lıppmann, F, 1973 Sedımentary Carbonate Minerals Springer, New York. N Y . 228 pp

Livingstone, D A , 1963 Chapter G Chemical composition of rivers and lakes U S Geol Surv, Prof Pap , 440-G GI-G64

Lohman, K E, 1964 Stratıgraphic and paleoecologic significance of the Mesozoic and Cenozoic diatoms of Calıfornı and Nevada In A T Cross (Editor). Palynology in Oil Exploration Soc Econ Palaeontol Mineral, Spec Publ, 11 58-66

Marshall, W L and Warankowskı, J M, 1980. Amorphous silica solubilities-II Effect of aqueous salt solutıons at $25^{\circ} \mathrm{C}$ Geochım Cosmochım Acta, 44 915-924

McCarraher, D B , 1970 The small playa lakes of Nebraska, their ecology, fisheries, and biological potentıal In C.C Reeves (Edıtor), Playa Lake Symposıum (1970) Int Center for Arıd and Semı-arıd Land Studies, Publ 4 15-23

McCullough, L A, 1977 Playa-lake and clastic deposition in Paleocene-Eocene Flagstaff Limestone, Wasatch Plateau, Utah Unpubl M S. Thesıs, Ohıo State University, 116 pp

McGookey, D P. 1958 Geology of the northern portion of the Fish Lake Plateau, Utah Unpubl Ph D Diss . Ohio State University

McGookey, D.P, 1960 Early Tertary stratigraphy of part of central Utah Bull Am Assoc Pet Geol, $44 \quad 589-615$

McLachlan. A J , 1975 The role of aquatic macrophytes in the recovery of the benthic faund of a tropical lake after a dry phase Lımnol Oceanogr, 19 743-755

Millot, G, Nahon, D., Paquet, H, Ruellan, A and Tardy, Y, 1977 L'épıgénıe calcaire des roches sllıcatées dans les encroutements carbonates en pays subarıde. Antıatlas, Maroc Scı Géol Bull, Strassbourg, 30 129-152

Molnar, B, Murvaı, M I and Hegyi-Pako, J, 1976, Recent lacustrine dolomite formation in the Great Hungarian Plain Acta Geol Scı Hungancae, 20 179-198

Mortimer, $\mathrm{C} \mathrm{H}, 1941$ The exchange of dissolved substances between mud and water in lakes Part $1 \mathrm{~J}$ Ecol, 29 280-329, Part 2 J Ecol, 30 147-201

Motts, W S . 1970 Some hydrologic and geologic processes influencing playa development in the western United States In C C Reeves (Editor), Playa Lake Symposium (1970) Int Center for Arid and Semi-arid Land Studies, Publ 4 89-106

Muller, G and Wagner, F, 1978 Holocene carbonate evolution in Lake Balaton (Hungary) a response to climate and impact of man In A Matter and ME Tucker (Editors). Modern and Ancient Lake Sedıments Int Assoc Sedımentol, Spec Publ, 2 57-81

Pelto, C R., 1956 A study of chalcedony Am J. Sc1, 254 32-50

Peterson, A R, 1976 Paleoenvironments of the Colton Formation, Colton, Utah Brigham Young Univ, Geol Stud. 23 3-26

Peterson. M N A and Von der Borch, C C, 1965 Chert modern inorganic deposition in a carbonate-precipitating locality Science, 149 1501-1503

Pettıohn, F J and Potter, P E, 1964 Atlas and Glossary of Prımary Sedımentary Structures Springer. New York, N.Y, 370 pp

Pittman, J S, 1959 Silica in Edwards Limestone. Travis County. Texas. In H A Ireland (Editor), Silica in Sedıments Soc Econ Palaeontol Mineral, Spec Publ, 7 121-134

Reeves, C C., 1968 Introduction to Paleolimnology. Elsevier, Amsterdam, 228 pp

Reeves, C C, 1972 Playa Lake Symposium (1970) Int Center for Arıd and Semi-arıd Land Studies, Publ 4

Reeves, C C , 1976 Calıche Origin, Classification, Morphology, and Uses Estacado Press, Texas, 233 pp

Ryder, R T . Fouch, T D and Elıson, J.T., 1976 Early Tertıary sedimentation in the western Uinı Basın. Utah Geol Soc Am Bull, 87 496-512 
Shepherd, W, 1972 Flint-Its Origin, Propertıes, and Uses Faber and Faber, London, 255 pp

Smoot, J.P, 1978 Origin of the carbonate sediments in the Wilkens Peak Member of the lacustrine Green

River Formation (Eocene), Wyoming. US A In A Matter and M E Tucker (Editors), Modern and

Ancient Lake Sediments Int Assoc Sedimentol, Spec Publ, 2 109-127

Spieker, E M , 1949 The Transition between the Colorado Plateau and the Great Basin in Central Utah Utah Geol Soc, Guidebook 4, 106 pp

Spieker, E.M and Reeside, J.B., 1925 Cretaceous and Tertiary formations of the Wasatch Plateau Utah Geol. Soc Am Bull. 36 435-454

Stanley, K.O and Collinson, J W, 1979 Depositional history of Paleocene-Lower Eocene Flagstaff Limestone and coeval rocks, central Utah Bull Am Assoc. Pet Geol. 63 311-323

Surdam, R C and Eugster, H -P , 1976, Mineral reactions in the sedimentary deposits of the Lake Magadi regıon, Kenya, Geol Soc. Am Bull, 87 1739-1752

Surdam, R C and Wolfbauer, C A, 1975. Green River Formation, Wyomıng a playa-lake complex Geol Soc Am Bull, 86 335-345

Swain, F M. 1956 Early Tertıry ostracode zones of Uinta Basın Intermountain Assoc Pet Geol. Guidebook, 7th Ann Field Conf, pp 125-139

Swetı, K. 1965 Dolomitization, silicification and calcitization patterns in Cambro-Ordovician oolıtes from northwest Scotland J Sediment Petrol, 35 928-938

Thıry, M, 1981 Sédımentatıon contınentale et altératıons associées calcıtısatıons, ferrugınısatıons, et silıcıfıcatıons-Les argiles plastıques du Sparnacien du Bassın de Parıs Scı. Géol Mém. Strassbourg. 64, $173 \mathrm{pp}$

Tome, K M , 1962 Clay mıneral diagenesis as a possıble source of silıca cement in sedimentary rocks $J$ Sediment Petrol, 32 26-28

Vatan, A, 1939. Les breches dans les terrains tertıares du centre de la France Soc Géol Fr, C R, 2204 $54-56$

Vollenweider, R.A, 1968 Scientific fundamentals of the eutrophification of lakes and flowing waters, with particular reference to $\mathrm{N}$ and $\mathrm{P}$ as factors in eutrophication Paris, Rep Organisation for Economic Cooperation and Development, DAS/CSI/68 27

Walkden, G M, 1974 Paleokarstic surfaces in Upper Visean (Carbonıferous) limestones of the Derbyshire block, England J Sediment Petrol, 44 1232-1247

Weaver, C E, 1958 The effects and geological significance of potassium "fixation" by expandable clay mınerals Am Mineral, 43 839-861

Weiss, M P, 1969 Oncolıtes, paleoecology, and Laramide tectonics, central Utah Bull Am Assoc Pet Geol, 53 1105-1120

Wells. N A, 1977 Paleocene-Eocene Lake Flagstaff of central Utah Unpubl M S Thesis, Ohıo State University, 174 pp

Wells, N A., Cloke, P L and Dawson, R S , 1979 Water chemistry durıng the development of Paleogene Lake Flagstaff of central Utah Geol Soc Am.. Abstr with Programs, 11, p 537

Wetzel, R G, 1975 Limnology. Saunders, Phıladelphıa, 743 pp

Wheeler, W H and Textoris, D A, 1978. Triassıc limestone and chert of playa orıgın in North Carolına J Sediment Petrol, 48 765-776

Willuamson, C R and Picard, M D , 1974 Petrology of the carbonate rocks of the Green River Formation (Eocene) J Sedıment Petrol, 44 738-759

Wolfbauer, C A and Surdam, R C , 1974 Orıgın of nonmarıne dolomites in Eocene Lake Gosıte, Green River Basin, Wyoming Geol Soc Am Bull , 85 1733-1740

Zawınskı, J, in prep Ph D dissertation on North Horn and Flagstaff vertebrates Ohıo State Unıversıty 